\title{
LEVEL II SCOUR ANALYSIS FOR BRIDGE 6 (STAMVT01000006) on VERMONT HIGHWAY 100, crossing the NORTH BRANCH OF THE HOOSIC RIVER, STAMFORD, VERMONT
}

U.S. Geological Survey

Open-File Report 97-216

Prepared in cooperation with

VERMONT AGENCY OF TRANSPORTATION

and

FEDERAL HIGHWAY ADMINISTRATION 


\section{LEVEL II SCOUR ANALYSIS FOR BRIDGE 6 (STAMVT01000006) on VERMONT HIGHWAY 100, crossing the NORTH BRANCH OF THE HOOSIC RIVER, STAMFORD, VERMONT \\ By ROBERT H. FLYNN}

U.S. Geological Survey Open-File Report 97-216

Prepared in cooperation with

VERMONT AGENCY OF TRANSPORTATION and

FEDERAL HIGHWAY ADMINISTRATION 


\title{
U.S. DEPARTMENT OF THE INTERIOR BRUCE BABBITT, Secretary
}

\author{
U.S. GEOLOGICAL SURVEY \\ Gordon P. Eaton, Director
}

For additional information write to:

District Chief

U.S. Geological Survey 361 Commerce Way

Pembroke, NH 03275-3718
Copies of this report may be purchased from:

U.S. Geological Survey

Branch of Information Services

Open-File Reports Unit

Box 25286

Denver, CO 80225-0286 


\section{CONTENTS}

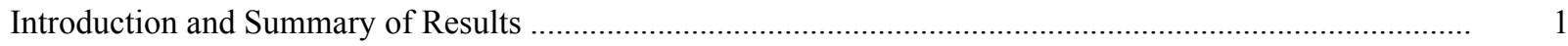

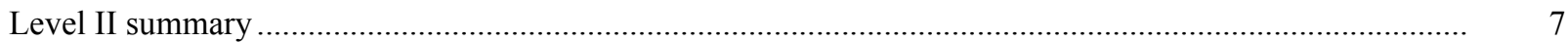

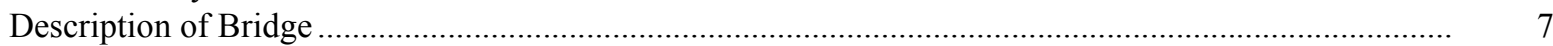

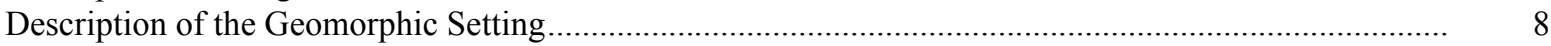

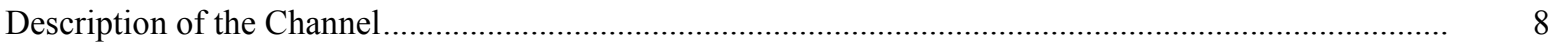

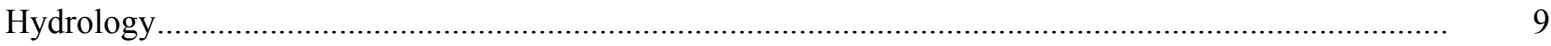

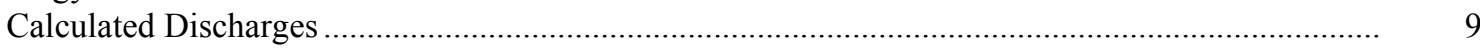

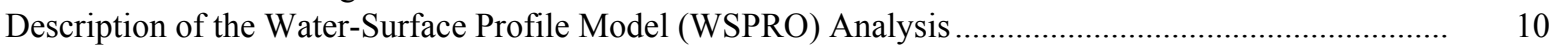

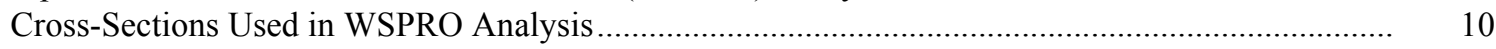

Data and Assumptions Used in WSPRO Model ...................................................................... 11

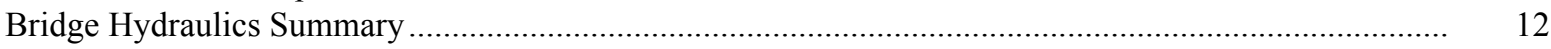

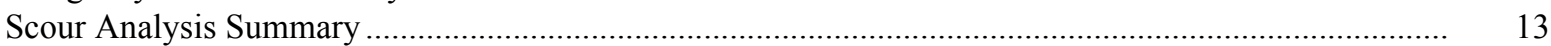

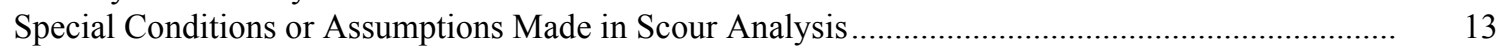

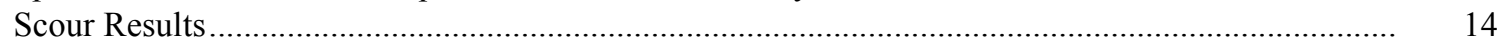

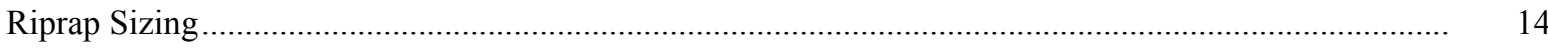

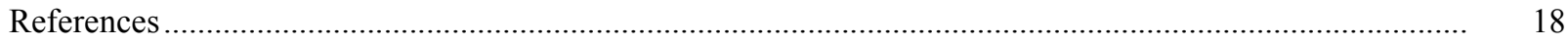

Appendixes:

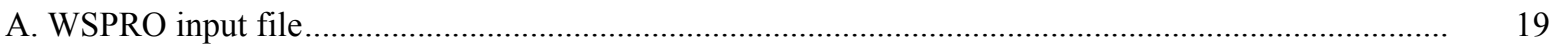

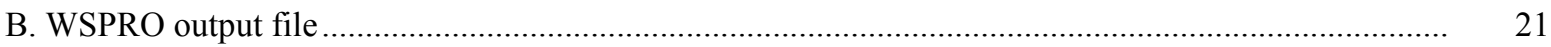

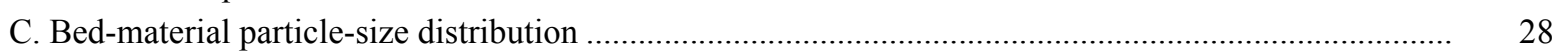

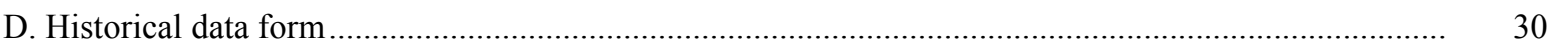

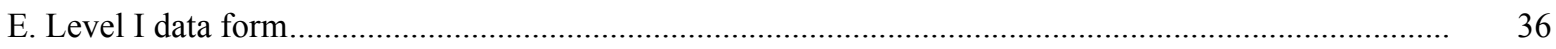

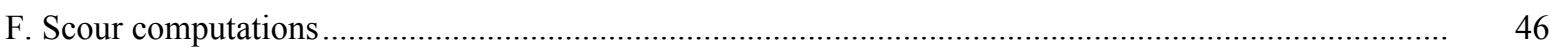

\section{FIGURES}

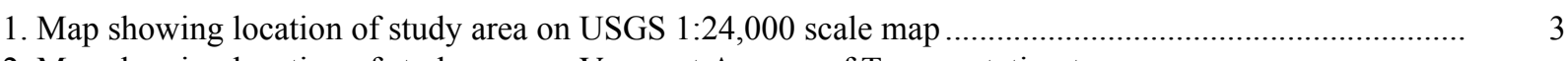

2. Map showing location of study area on Vermont Agency of Transportation town
highway map

3. Structure STAMVT01000006 viewed from upstream (July 31, 1996) …...............................................

4. Downstream channel viewed from structure STAMVT01000006 (July 31, 1996).............................. 5

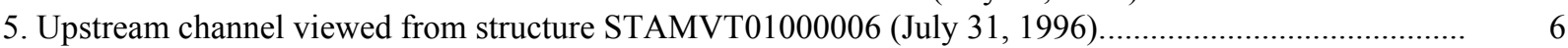

6. Structure STAMVT01000006 viewed from downstream (July 31, 1996). ......................................... 6

7. Water-surface profiles for the 100- and 500-year discharges at structure

STAMVT01000006 on Vermont Highway 100, crossing the North Branch of the

Hoosic River, Stamford, Vermont.

8. Scour elevations for the 100- and 500-year discharges at structure

STAMVT01000006 on Vermont Highway 100, crossing the North Branch of the

Hoosic River, Stamford, Vermont.

\section{TABLES}

1. Remaining footing/pile depth at abutments for the 100-year discharge at structure

STAMVT01000006 on Vermont Highway 100, crossing the North Branch of the

Hoosic River, Stamford, Vermont

2. Remaining footing/pile depth at abutments for the 500-year discharge at structure

STAMVT01000006 on Vermont Highway 100, crossing the North Branch of the

Hoosic River, Stamford, Vermont ....

5




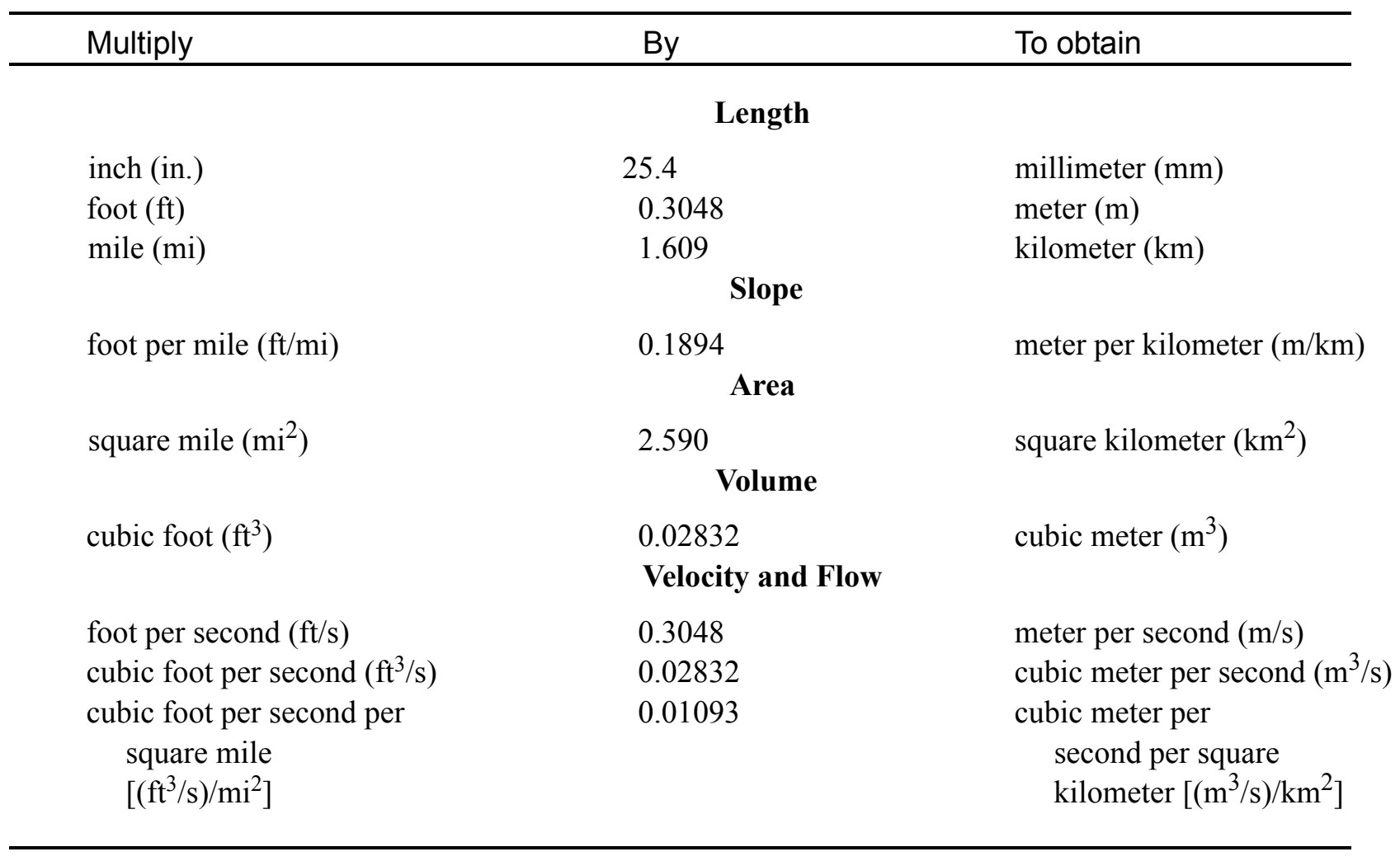

\section{OTHER ABBREVIATIONS}

$\begin{array}{lrlr}\mathrm{BF} & \text { bank full } & \text { LWW } & \text { left wingwall } \\ \mathrm{cfs} & \text { cubic feet per second } & \text { MC } & \text { main channel } \\ \mathrm{D}_{50} & \text { median diameter of bed material } & \text { RAB } & \text { right abutment } \\ \mathrm{DS} & \text { downstream } & \text { RABUT } & \text { face of right abutment } \\ \mathrm{elev} & \text { elevation } & \text { RB } & \text { right bank } \\ \mathrm{f} / \mathrm{p} & \text { flood plain } & \text { ROB } & \text { right overbank } \\ \mathrm{ft}^{2} & \text { square feet } & \text { RWW } & \text { right wingwall } \\ \mathrm{ft} / \mathrm{ft} & \text { feet per foot } & \text { TH } & \text { town highway } \\ \mathrm{JCT} & \text { junction } & \text { UB } & \text { under bridge } \\ \mathrm{LAB} & \text { left abutment } & \text { US } & \text { upstream } \\ \mathrm{LABUT} & \text { face of left abutment } & \text { USGS } & \text { United States Geological Survey } \\ \mathrm{LB} & \text { left bank } & \text { VTAOT Vermont Agency of Transportation } \\ \mathrm{LOB} & \text { left overbank } & \text { WSPRO } & \text { water-surface profile model }\end{array}$

In this report, the words "right" and "left" refer to directions that would be reported by an observer facing downstream. Sea level: In this report, "sea level" refers to the National Geodetic Vertical Datum of 1929-- a geodetic datum derived from a general adjustment of the first-order level nets of the United States and Canada, formerly called Sea Level Datum of 1929.

In the appendices, the above abbreviations may be combined. For example, USLB would represent upstream left bank. 


\title{
LEVEL II SCOUR ANALYSIS FOR BRIDGE 6 (STAMVT01000006) ON VERMONT HIGHWAY 100, CROSSING THE NORTH BRANCH OF THE HOOSIC RIVER, STAMFORD, VERMONT
}

\author{
By Robert H. Flynn
}

\section{INTRODUCTION AND SUMMARY OF RESULTS}

This report provides the results of a detailed Level II analysis of scour potential at structure STAMVT01000006 on Vermont Highway 100 crossing the North Branch of the Hoosic River, Stamford, Vermont (figures 1-8). A Level II study is a basic engineering analysis of the site, including a quantitative analysis of stream stability and scour (U.S. Department of Transportation, 1993). Results of a Level I scour investigation also are included in Appendix E of this report. A Level I investigation provides a qualitative geomorphic characterization of the study site. Information on the bridge, gleaned from Vermont Agency of Transportation (VTAOT) files, was compiled prior to conducting Level I and Level II analyses and is found in Appendix D.

The site is in the Green Mountain section of the New England physiographic province in southern Vermont. The $8.61-\mathrm{mi}^{2}$ drainage area is in a predominantly rural and forested basin. In the vicinity of the study site, the surface cover is grass with forest along the immediate banks throughout the reach.

In the study area, the North Branch of the Hoosic River has an incised, sinuous channel with a slope of approximately $0.02 \mathrm{ft} / \mathrm{ft}$, an average channel top width of $44 \mathrm{ft}$ and an average bank height of $4 \mathrm{ft}$. The channel bed material ranges from sand to boulder with a median grain size $\left(\mathrm{D}_{50}\right)$ of $97.4 \mathrm{~mm}(0.320 \mathrm{ft})$. The geomorphic assessment at the time of the Level I and Level II site visit on July 31, 1996, indicated that the reach was stable.

The Vermont Highway 100 crossing of the North Branch of the Hoosic River is a 99-ftlong, two-lane bridge consisting of one 97-foot steel-beam span (Vermont Agency of Transportation, written communication, September 28, 1995). The bridge is supported by vertical, concrete abutments with wingwalls. The channel is skewed approximately 60 degrees to the opening and the opening-skew-to-roadway is also 60 degrees. 
The scour protection measures at the site included type-1 stone fill (less than 12 inches diameter) along the downstream left bank. Type-2 (less than 36 inches diameter) stone fill was found along the upstream left bank and the downsteam right bank. Additional details describing conditions at the site are included in the Level II Summary and Appendices D and E.

Scour depths and rock rip-rap sizes were computed using the general guidelines described in Hydraulic Engineering Circular 18 (Richardson and others, 1995). Total scour at a highway crossing is comprised of three components: 1) long-term streambed degradation; 2) contraction scour (due to accelerated flow caused by a reduction in flow area at a bridge) and; 3) local scour (caused by accelerated flow around piers and abutments). Total scour is the sum of the three components. Equations are available to compute depths for contraction and local scour and a summary of the results of these computations follows.

Contraction scour for all modelled flows ranged from 0.7 to $2.1 \mathrm{ft}$. The worst-case contraction scour occurred at the 500-year discharge. Abutment scour ranged from 18.8 to $19.7 \mathrm{ft}$ along the right abutment and from 2.8 to $6.8 \mathrm{ft}$ along the left abutment. The worstcase abutment scour occurred at the 500-year discharge. Additional information on scour depths and depths to armoring are included in the section titled "Scour Results". Scouredstreambed elevations, based on the calculated scour depths, are presented in tables 1 and 2 . A cross-section of the scour computed at the bridge is presented in figure 8. Scour depths were calculated assuming an infinite depth of erosive material and a homogeneous particlesize distribution.

It is generally accepted that the Froehlich equation (abutment scour) gives "excessively conservative estimates of scour depths" (Richardson and others, 1995, p. 47). Usually, computed scour depths are evaluated in combination with other information including (but not limited to) historical performance during flood events, the geomorphic stability assessment, existing scour protection measures, and the results of the hydraulic analyses. Therefore, scour depths adopted by VTAOT may differ from the computed values documented herein. 


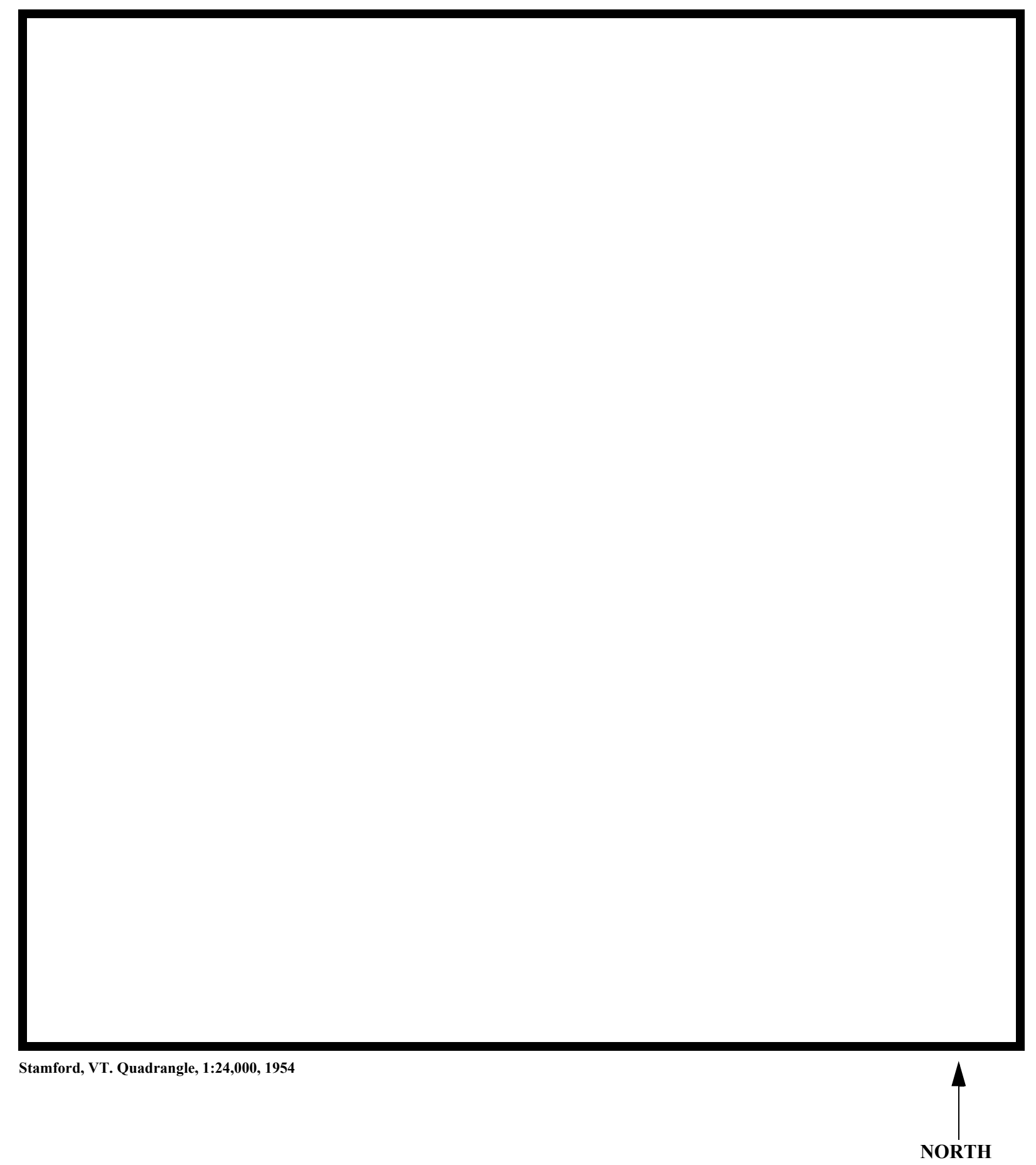

Figure 1. Location of study area on USGS 1:24,000 scale map. 
Figure 2. Location of study area on Vermont Agency of Transportation town highway map. 

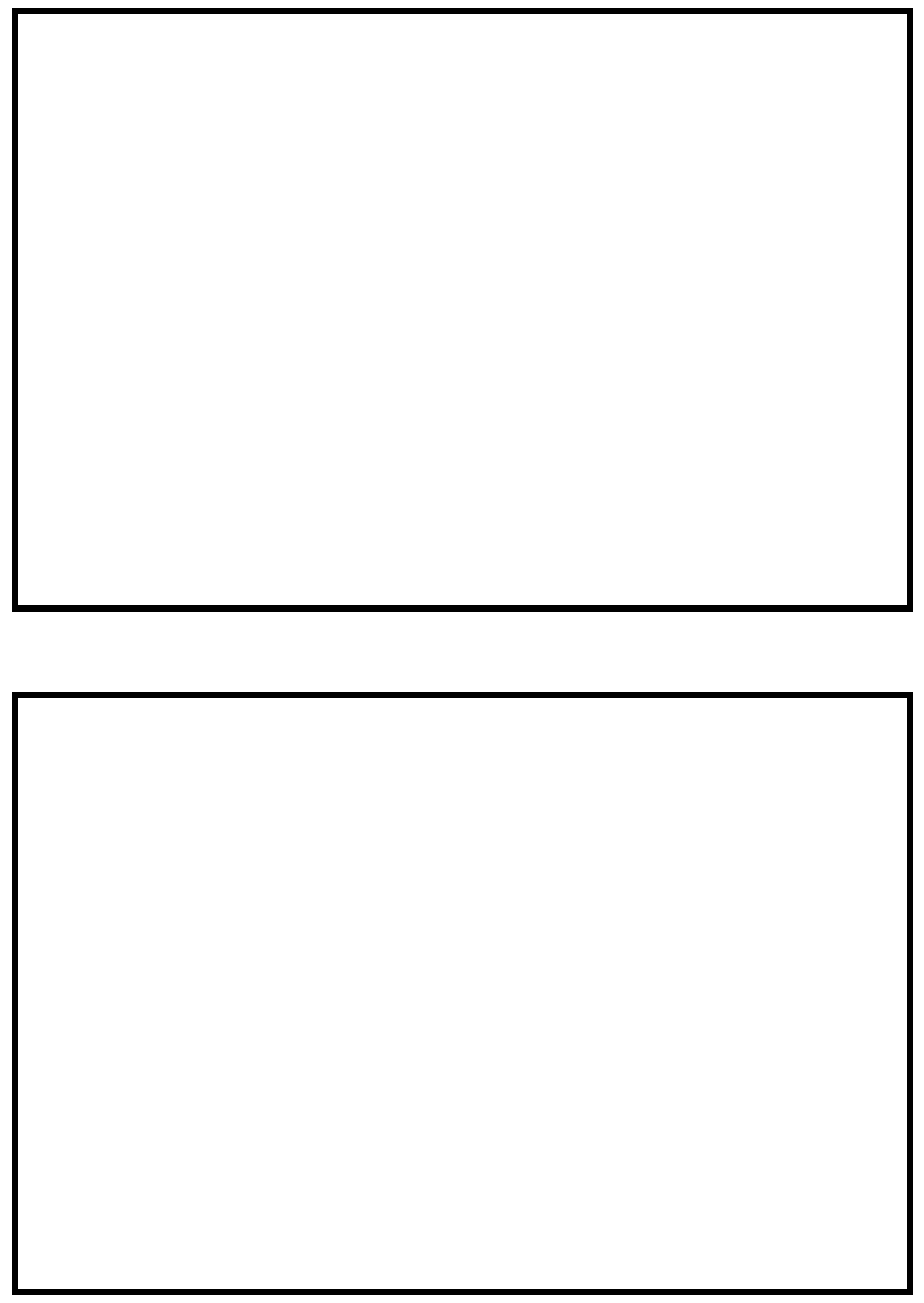

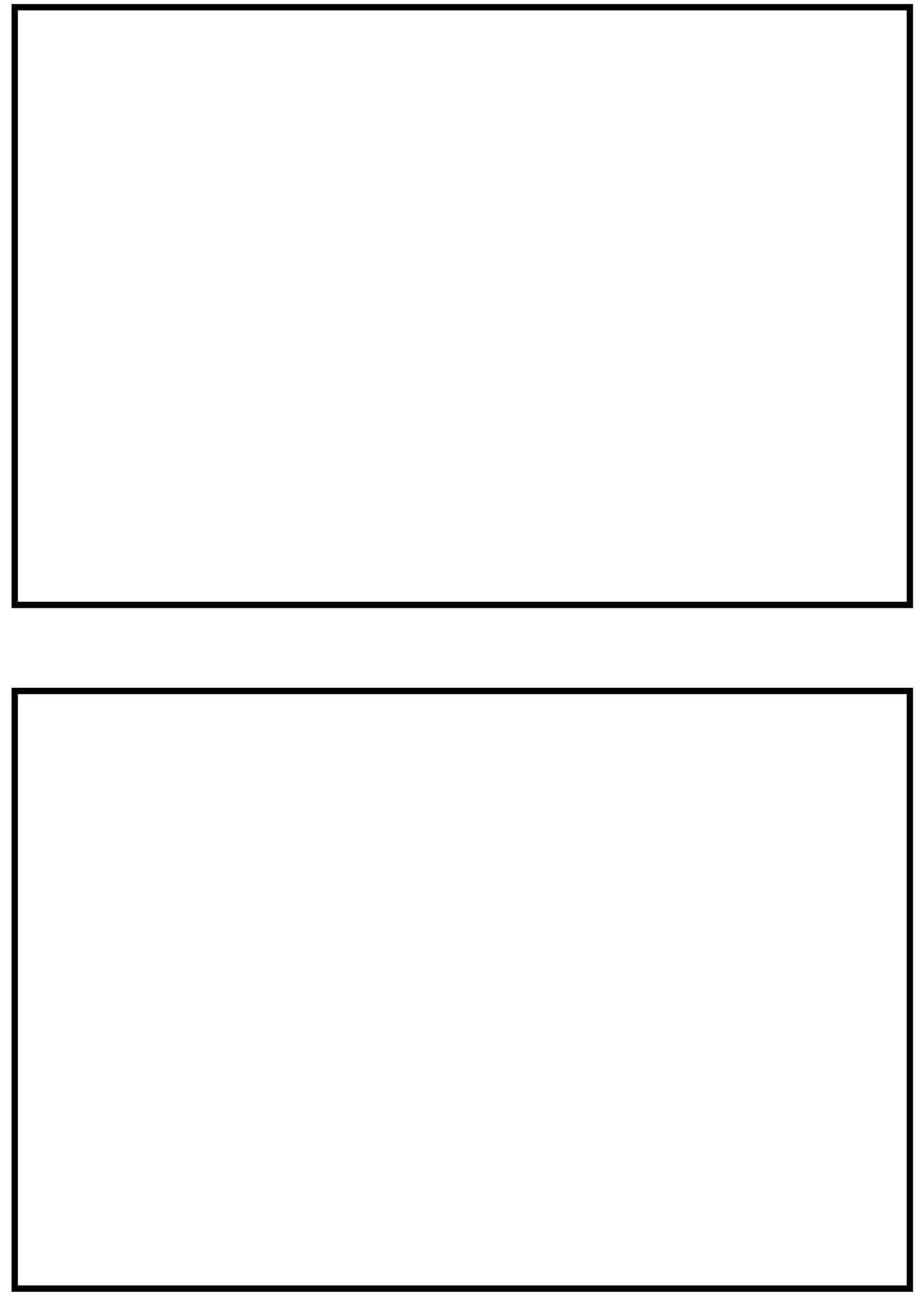


\section{LEVEL II SUMMARY}

\begin{tabular}{llllll} 
Structure Number & STAMVT01000006 & & \multicolumn{3}{c}{ North Branch Hoosic River } \\
Stream & & & \\
County & Bennington & Road & VT 100 & District & 1
\end{tabular}

\section{Description of Bridge}

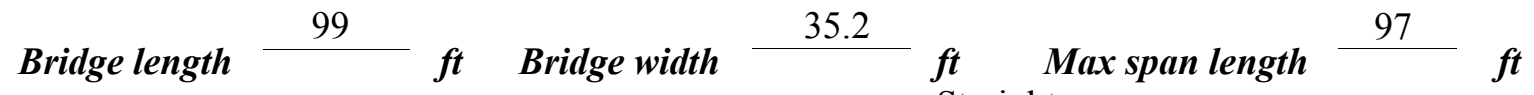
Alignment of bridge to road (on curve or straight)

Abutment type Vertical, concrete

\section{Stone fill on abutment?}

$$
\text { No }
$$

\section{Embankment type} Straight

namamintinu af atan fill Type-1 stone fill was found along the downstream left bank. Type-2
Sloping

$7 / 31 / 96$

stone fill was found along the upstream left bank and downstream right bank.

Abutments are concrete.

$\cdots+\ldots, \ldots$

\section{Y}

Is bridge skewed to flood flow according to No r survey? Angle

There is a mild channel bend in the upstream reach.

Debris accumulation on bridge at time of Level I or Level II site visit:

\begin{tabular}{|c|c|c|c|}
\hline & $\begin{array}{c}\text { Date of insnortion } \\
7 / 31 / 96 \\
\end{array}$ & $\begin{array}{l}\text { Percent of aham } 0 \\
\text { blocked inortzontatly }\end{array}$ & $\begin{array}{l}\text { Percent of } 0 \\
\text { blocked verticatty }\end{array}$ \\
\hline Level I & $7 / 31 / 96$ & 0 & 0 \\
\hline
\end{tabular}

Level II

High. There are large boulders ( 3 to $6 \mathrm{ft}$ in diameter), scarred trees along the banks and downed trees in the channel upstream.

Potential for debris

Boulders and downed trees upstream may affect flow.

Dosrriho any, fonturos noar ar at tho hridoo that mav, affort flow, (includo ahsorvation dato) 


\section{Description of the Geomorphic Setting}

General topography The channel is located within a wide, flat to slightly irregular flood plain in a moderate relief valley setting.

Geomorphic conditions at bridge site: downstream (DS), upstream (US)

Date of inspection $\quad 7 / 31 / 96$

DS left: $\quad$ Moderately sloped channel bank to a wide flood plain.

DS right: $\quad$ Moderately sloped channel bank to a wide flood plain.

US left: $\quad$ Moderately sloped channel bank to a wide flood plain.

US right: $\quad$ Moderately sloped channel bank to a wide flood plain.

\section{Description of the Channel}

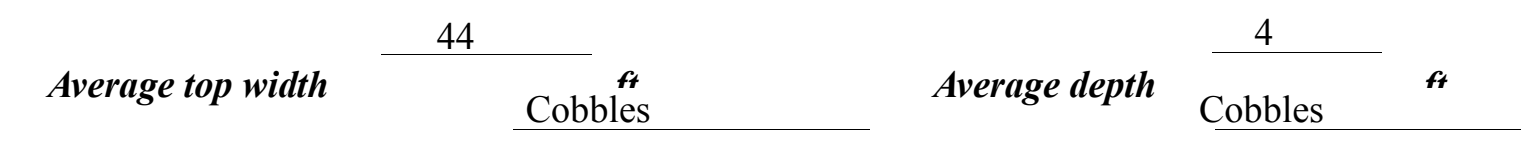

Predominant bed material

Bank material

Sinuous with semi-

âluvial channel boundaries and a wide flood plain.

$7 / 31 / 96$

Vegetative co ${ }^{1}$ Grass with forest along immediate banks.

DS left: $\quad$ Grass with forest along immediate banks.

DS right: $\quad$ Grass with forest along immediate banks.

US left: $\quad$ Grass with forest along immediate banks.

US right:

No

Do banks appear stable? The upstream banks, are scalloped and eroded with cut banks and exposed tree roots evident along both banks. The downstream banks are also scalloped and have
date of observatton. exposed tree roots. 7/31/96

The assessment of

7/31/96 noted downed trees along both upstream banks and among large boulders Describe any obstructions in channel and date of observation.

( $3 \mathrm{ft}$ to $6 \mathrm{ft}$ diameter) upstream. 


\title{
Hydrology
}

Drainage area $\stackrel{8.61}{\boldsymbol{m i}^{2}}$

Percentage of drainage area in physiographic provinces: (approximate)

Physiographic province/section

New England / Green Mountain
Percent of drainage area 100

\begin{abstract}
Is drainage area considered rural or urban?
Rural None. urbanization:-

Describe any significant
\end{abstract}

Is there a USGS gage on the stream of interest?

No

USGS gage description

USGS gage number

Gage drainage area $\mathrm{mi}^{2}$

$--$

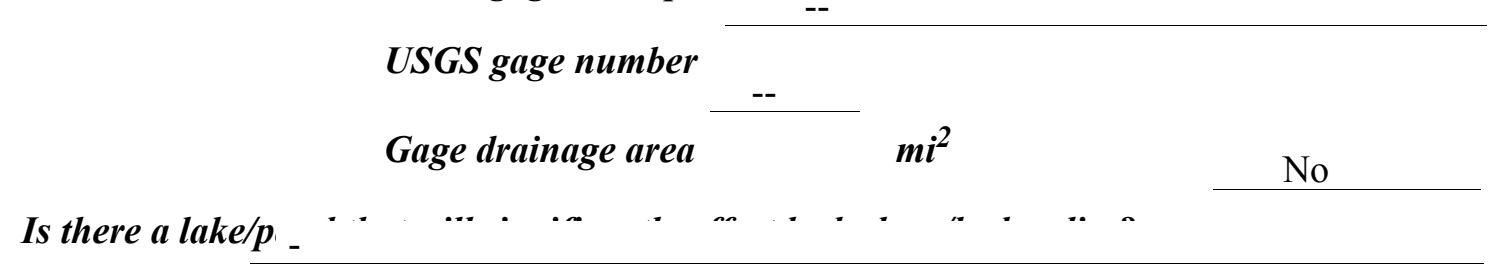

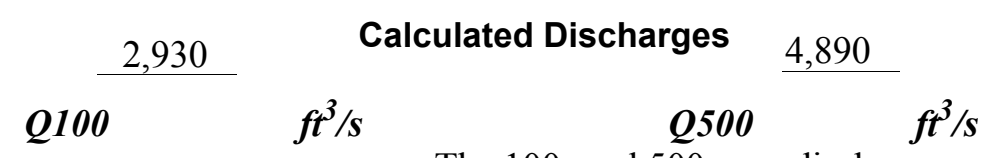

The 100- and 500-year discharges are based on a

drainage area relationship [(8.6/8.8)exp 0.75] with the North Branch of the Hoosic River upstream of the Sumner Brook confluence which has flood frequency estimates available from a Federal Emergency Management Agency flood insurance study for the town Stamford (Federal Emergency Management Agency, 1978). The drainage area above upstream of the Sumner Brook confluence is 8.8 square miles. (Benson, 1962; Johnson and Tasker, 1974; FHWA, 1983; Potter, 1957a\&b; Talbot, 1887) 


\section{Description of the Water-Surface Profile Model (WSPRO) Analysis}

Datum for WSPRO analysis (USGS survey, sea level, VTAOT plans)

USGS survey

Datum tie between USGS survey and VTAOT plans

Add $717.8 \mathrm{ft}$ to USGS arbitrary

survey datum to obtain VTAOT plans datum (NGVD).

Description of reference marks used to determine USGS datum. $\quad$ RM1 is a VTAOT

survey disk on top of the right end of the downstream bridge rail (elev. $501.30 \mathrm{ft}$, arbitrary

survey datum). RM2 is a chiseled $\mathrm{X}$ on top of the curb at the upstream end of the left abutment

(elev. $500.87 \mathrm{ft}$, arbitrary survey datum).

\section{Cross-Sections Used in WSPRO Analysis}

\begin{tabular}{cccl}
\hline${ }^{1}$ Cross-section & $\begin{array}{c}\text { Section } \\
\text { Reference } \\
\text { Distance } \\
\text { (SRD) } \text { in feet }\end{array}$ & $\begin{array}{c}{ }^{2} \text { Cross-section } \\
\text { development }\end{array}$ & \multicolumn{1}{c}{ Comments } \\
\hline EXITX & -98 & 1 & $\begin{array}{l}\text { Exit section } \\
\text { Downstream Full-valley } \\
\text { section (Templated from } \\
\text { EXITX) }\end{array}$ \\
FULLV & 0 & 2 & $\begin{array}{l}\text { Bridge section } \\
\text { RRIDG }\end{array}$ \\
RDWAY & 0 & 1 & $\begin{array}{l}\text { Road Grade section } \\
\text { Modelled Approach sec- } \\
\text { tion (Templated from } \\
\text { APTEM) }\end{array}$ \\
APPRO & 115 & 1 & $\begin{array}{l}\text { Approach section as sur- } \\
\text { veyed (Used as a tem- } \\
\text { plate) }\end{array}$ \\
\hline
\end{tabular}

${ }^{1}$ For location of cross-sections see plan-view sketch included with Level I field form, Appendix E.

For more detail on how cross-sections were developed see WSPRO input file. 


\section{Data and Assumptions Used in WSPRO Model}

Hydraulic analyses of the reach were done by use of the Federal Highway Administration's WSPRO step-backwater computer program (Shearman and others, 1986, and Shearman, 1990). The analyses reported herein reflect conditions existing at the site at the time of the study. Furthermore, in the development of the model it was necessary to assume no accumulation of debris or ice at the site. Results of the hydraulic model are presented in the Bridge Hydraulic Summary, Appendix B, and figure 7.

Channel roughness factors (Manning's " $n$ ") used in the hydraulic model were estimated using field inspections at each cross section following the general guidelines described by Arcement and Schneider (1989). Final adjustments to the values were made during the modelling of the reach. Channel " $\mathrm{n}$ " values for the reach ranged from 0.050 to 0.060 , and overbank " $\mathrm{n}$ " values ranged from 0.055 to 0.090 .

Normal depth at the exit section (EXITX) was assumed as the starting water surface. This depth was computed by use of the slope-conveyance method outlined in the user's manual for WSPRO (Shearman, 1990). The slope used was $0.016 \mathrm{ft} / \mathrm{ft}$ which was determined from the 100-year water surface profile slope in the flood insurance study for the town of Stamford (Federal Emergency Management Agency, 1978)

The surveyed approach section (APTEM) was moved along the approach channel slope $(0.010 \mathrm{ft} / \mathrm{ft})$ to establish the modelled approach section (APPRO), one bridge length upstream of the upstream face as recommended by Shearman and others (1986). This approach also provides a consistent method for determining scour variables. 


\section{Bridge Hydraulics Summary}

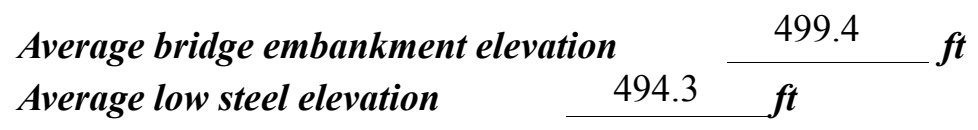

100-year discharge $\quad 2,930 \quad \mathrm{ft}^{3} / \mathrm{s}$

Water-surface elevation in bridge opening $\quad 495.0 \quad f t$

Road overtopping? ___ Y Discharge over road ___ $27 \quad \mathrm{ft}^{3} / \mathrm{s}$

Area of flow in bridge opening $\quad 268 \quad \boldsymbol{f t}^{2}$

Average velocity in bridge opening $10.8 \quad \mathrm{ft} / \mathrm{s}$

$\begin{array}{lll}\text { Maximum WSPRO tube velocity at bridge } & 12.3 \mathrm{ft} / \mathrm{s}\end{array}$

Water-surface elevation at Approach section with bridge 498.9

Water-surface elevation at Approach section without bridge $\quad 497.8$

Amount of backwater caused by bridge $\quad 1.1$ it

500-year discharge $\quad 4,890 \quad \mathrm{ft}^{3} / \mathrm{s}$

Water-surface elevation in bridge opening $\quad 495.0 \mathrm{ft}$

Road overtopping? ___ Y Discharge over road __ 1,595 $\mathrm{ft}^{3} / \mathrm{s}$

Area of flow in bridge opening $\quad 268 \quad \mathrm{ft}^{2}$

Average velocity in bridge opening $12.3 \mathrm{ft} / \mathrm{s}$

Maximum WSPRO tube velocity at bridge 13.9 's

Water-surface elevation at Approach section with bridge 501.7

Water-surface elevation at Approach section without bridge $\quad 500.0$

Amount of backwater caused by bridge $\quad 1.7$,t

Incipient overtopping discharge $\quad 2,830 \mathrm{ft}^{3} / \mathrm{s}$

Water-surface elevation in bridge opening $495.0 \quad t$

Area of flow in bridge opening $\quad 268 \quad \mathbf{f t}^{2}$

Average velocity in bridge opening $\quad 10.6 \quad \mathrm{ft} / \mathrm{s}$

Maximum WSPRO tube velocity at bridge $\quad 12.0 \mathrm{ft} / \mathrm{s}$

Water-surface elevation at Approach section with bridge

Water-surface elevation at Approach section without bridge

498.7

Amount of backwater caused by bridge $\quad 1.1$ it 


\section{Scour Analysis Summary}

\section{Special Conditions or Assumptions Made in Scour Analysis}

Scour depths were computed using the general guidelines described in Hydraulic Engineering Circular 18 (Richardson and others, 1995). Scour depths were calculated assuming an infinite depth of erosive material and a homogeneous particle-size distribution. The results of the scour analysis are presented in tables 1 and 2 and a graph of the scour depths is presented in figure 8 .

All modeled discharges resulted in submerged orifice flow. Contraction scour at bridges with orifice flow is best estimated by use of the Chang pressure-flow scour equation (oral communication, J. Sterling Jones, October 4, 1996). Thus, the Chang equation (Richardson and others, 1995, pp. 145-146) was applied to compute the contraction scour for these discharges. The results of Laursen's clear-water contraction scour equation (Richardson and others, 1995, p. 32, equation 20) were also computed and can be found in appendix F. The 500-year discharge model resulted in the worst case contraction scour with a scour depth of $2.1 \mathrm{ft}$. The computed depths to streambed armoring suggest armoring will not limit the depth of contraction scour.

Abutment scour at the right abutment was computed by use of the Froehlich equation (Richardson and others, 1995, p. 48, equation 28). Variables for the Froehlich equation include the Froude number of the flow approaching the embankments, the length of the embankment blocking flow, and the depth of flow approaching the embankment less any roadway overtopping.

Scour at the left abutment was computed by use of the HIRE equation (Richardson and others, 1995, p. 49, equation 29) because the HIRE equation is recommended when the length to depth ratio of the embankment blocking flow exceeds 25 . The variables used by the HIRE abutment-scour equation are defined the same as those defined for the Froehlich abutment-scour equation. 


\section{Scour Results}

100-yr discharge 500-yr discharge

(Scour depths in feet)
Incipient overtopping discharge

Main channel

Live-bed scour

Clear-water scour

Depth to armoring

Left overbank

Right overbank

Local scour:

Abutment scour

Left abutment

Right abutment

Pier scour

Pier 1

Pier 2

Pier 3

\section{Abutments:}

Left abutment

Right abutment

Piers:

Pier 1

Pier 2

2.818 .8

19.7

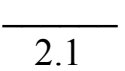

$8.516 .8^{-}$

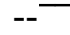

$--$

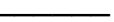

$7.5^{-}$

--

$3.36 .8^{-}$

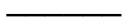

$-$

$-$




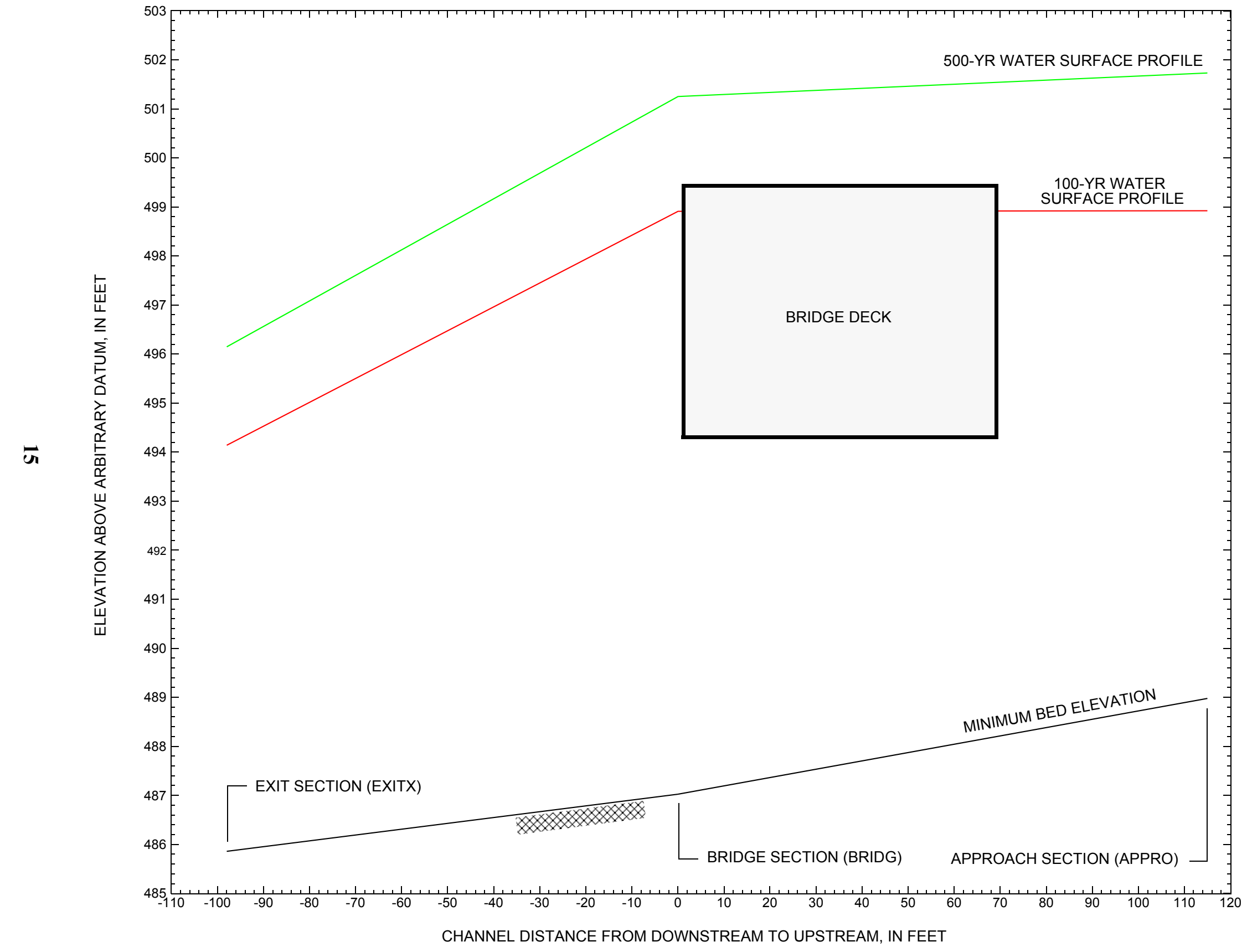

Figure 7. Water-surface profiles for the 100- and 500-yr discharges at structure STAMVT01000006 on Vermont Highway 100, crossing North Branch of the Hoosic River, Stamford, Vermont. 


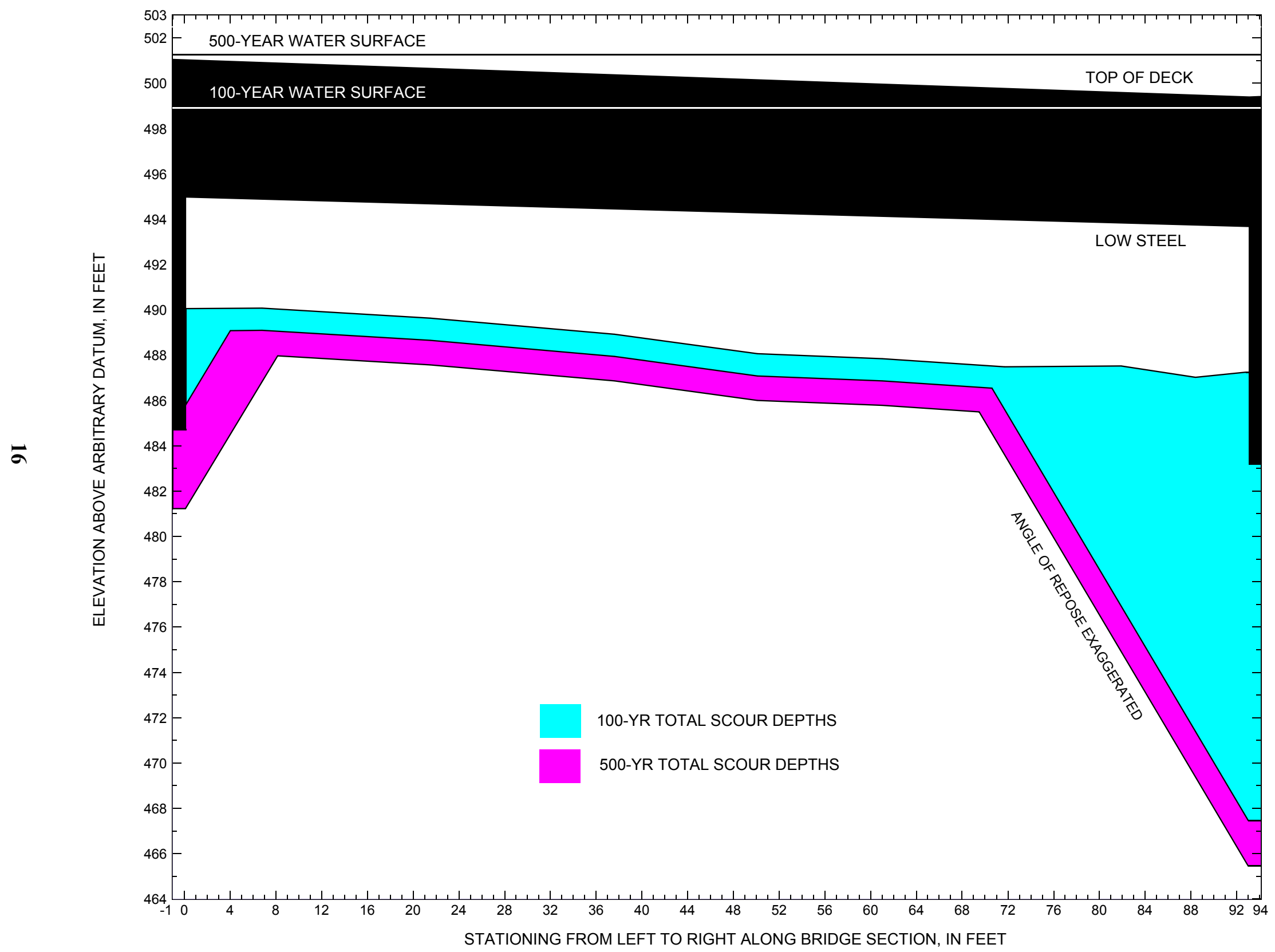

Figure 8. Scour elevations for the 100-yr and 500-yr discharges at structure STAMVT01000006 on Vermont Highway 100, crossing North Branch of the Hoosic River, Stamford, Vermont. 
Table 1. Remaining footing/pile depth at abutments for the 100-year discharge at structure STAMVT01000006 on Vermont Highway 100 , crossing North Branch of the Hoosic River, Stamford, Vermont.

[VTAOT, Vermont Agency of Transportation; --,no data]

\begin{tabular}{|c|c|c|c|c|c|c|c|c|c|c|c|}
\hline Description & Station $^{1}$ & $\begin{array}{l}\text { VTAOT } \\
\text { bridge seat } \\
\text { elevation } \\
\text { (feet) }\end{array}$ & $\begin{array}{c}\text { Surveyed } \\
\text { minimum } \\
\text { low-chord } \\
\text { elevation } \\
\text { (feet) }\end{array}$ & $\begin{array}{l}\text { Bottom of } \\
\text { footing } \\
\text { elevation } \\
\text { (feet) }\end{array}$ & $\begin{array}{c}\text { Channel } \\
\text { elevation at } \\
\text { abutment/ } \\
\text { pier }^{2} \\
\text { (feet) }\end{array}$ & $\begin{array}{l}\text { Contraction } \\
\text { scour depth } \\
\text { (feet) }\end{array}$ & $\begin{array}{l}\text { Abutment } \\
\text { scour } \\
\text { depth } \\
\text { (feet) }\end{array}$ & $\begin{array}{l}\text { Pier } \\
\text { scour } \\
\text { depth } \\
\text { (feet) }\end{array}$ & $\begin{array}{l}\text { Depth of } \\
\text { total scour } \\
\text { (feet) }\end{array}$ & $\begin{array}{c}\text { Elevation of } \\
\text { scour }^{2} \\
\text { (feet) }\end{array}$ & $\begin{array}{c}\text { Remaining } \\
\text { footing/pile } \\
\text { depth } \\
\text { (feet) }\end{array}$ \\
\hline \multicolumn{12}{|c|}{100 -yr. discharge is 2,930 cubic-feet per second } \\
\hline Left abutment & 0.0 & 1212.4 & 495.0 & 484.7 & 490.1 & 1.0 & 3.3 & -- & 4.3 & 485.8 & 1.1 \\
\hline Right abutment & 93.1 & 1211.3 & 493.7 & 483.2 & 487.3 & 1.0 & 18.8 & -- & 19.8 & 467.5 & -15.7 \\
\hline
\end{tabular}

1.Measured along the face of the most constricting side of the bridge.

2.Arbitrary datum for this study.

Table 2. Remaining footing/pile depth at abutments for the 500-year discharge at structure STAMVT01000006 on Vermont Highway 100, crossing North Branch of the Hoosic River, Stamford, Vermont.

[VTAOT, Vermont Agency of Transportation; --, no data]

\begin{tabular}{|c|c|c|c|c|c|c|c|c|c|c|c|}
\hline Description & Station $^{1}$ & $\begin{array}{c}\text { VTAOT } \\
\text { bridge seat } \\
\text { elevation } \\
\text { (feet) }\end{array}$ & $\begin{array}{l}\text { Surveyed } \\
\text { minimum } \\
\text { low-chord } \\
\text { elevation } \\
\text { (feet) }\end{array}$ & $\begin{array}{l}\text { Bottom of } \\
\text { footing } \\
\text { elevation } \\
\text { (feet) }\end{array}$ & $\begin{array}{c}\text { Channel } \\
\text { elevation at } \\
\text { abutment/ } \\
\text { pier }^{2} \\
\text { (feet) }\end{array}$ & $\begin{array}{l}\text { Contraction } \\
\text { scour depth } \\
\text { (feet) }\end{array}$ & $\begin{array}{l}\text { Abutment } \\
\text { scour } \\
\text { depth } \\
\text { (feet) }\end{array}$ & $\begin{array}{l}\text { Pier } \\
\text { scour } \\
\text { depth } \\
\text { (feet) }\end{array}$ & $\begin{array}{l}\text { Depth of } \\
\text { total scour } \\
\text { (feet) }\end{array}$ & $\begin{array}{c}\text { Elevation of } \\
\text { scour }^{2} \\
\text { (feet) }\end{array}$ & $\begin{array}{c}\text { Remaining } \\
\text { footing/pile } \\
\text { depth } \\
\text { (feet) }\end{array}$ \\
\hline \multicolumn{12}{|c|}{ 500-yr. discharge is 4,890 cubic-feet per second } \\
\hline Left abutment & 0.0 & 1212.4 & 495.0 & 484.7 & 490.1 & 2.1 & 6.8 & -- & 8.9 & 481.2 & -3.5 \\
\hline Right abutment & 93.1 & 1211.3 & 493.7 & 483.2 & 487.3 & 2.1 & 19.7 & -- & 21.8 & 465.5 & -17.7 \\
\hline
\end{tabular}

1.Measured along the face of the most constricting side of the bridge.

2.Arbitrary datum for this study. 


\section{SELECTED REFERENCES}

Arcement, G.J., Jr., and Schneider, V.R., 1989, Guide for selecting Manning's roughness coefficients for natural channels and flood plains: U.S. Geological Survey Water-Supply Paper 2339, 38 p.

Barnes, H.H., Jr., 1967, Roughness characteristics of natural channels: U.S. Geological Survey Water-Supply Paper 1849,213 p.

Benson, M. A., 1962, Factors Influencing the Occurrence of Floods in a Humid Region of Diverse Terrain: U.S. Geological Survey WaterSupply Paper 1580-B, 64 p.

Brown, S.A. and Clyde, E.S., 1989, Design of riprap revetment: Federal Highway Administration Hydraulic Engineering Circular No. 11, Publication FHWA-IP-89-016, 156 p.

Federal Highway Administration, 1983, Runoff estimates for small watersheds and development of sound design: Federal Highway Administration Report FHWA-RD-77-158

Federal Emergency Management Agency, 1978, Flood Insurance Study, Town of Stamford, Bennington County, Vermont: Washington, D.C., January 1978.

Froehlich, D.C., 1989, Local scour at bridge abutments in Ports, M.A., ed., Hydraulic Engineering--Proceedings of the 1989 National Conference on Hydraulic Engineering: New York, American Society of Civil Engineers, p. 13-18.

Hayes, D.C.,1993, Site selection and collection of bridge-scour data in Delaware, Maryland, and Virginia: U.S. Geological Survey WaterResources Investigation Report 93-4017, 23 p.

Interagency Advisory Committee on Water Data, 1982, Guidelines for determining flood flow frequency: U.S. Geological Survey, Bulletin 17B of the Hydrology Subcommittee, 190 p.

Johnson, C.G. and Tasker, G.D.,1974, Progress report on flood magnitude and frequency of Vermont streams: U.S. Geological Survey OpenFile Report 74-130, 37 p.

Lagasse, P.F., Schall, J.D., Johnson, F., Richardson, E.V., Chang, F., 1995, Stream Stability at Highway Structures: Federal Highway Administration Hydraulic Engineering Circular No. 20, Publication FHWA-IP-90-014, 144 p.

Laursen, E.M., 1960, Scour at bridge crossings: Journal of the Hydraulics Division, American Society of Civil Engineers, v. 86, no. HY2, p. 39-53.

Potter, W. D., 1957a, Peak rates of runoff in the Adirondack, White Mountains, and Maine woods area, Bureau of Public Roads

Potter, W. D., 1957b, Peak rates of runoff in the New England Hill and Lowland area, Bureau of Public Roads

Richardson, E.V. and Davis, S.R., 1995, Evaluating scour at bridges: Federal Highway Administration Hydraulic Engineering Circular No. 18, Publication FHWA-IP-90-017, 204 p.

Richardson, E.V., Simons, D.B., and Julien, P.Y., 1990, Highways in the river environment: Federal Highway Administration Publication FHWA-HI-90-016.

Ritter, D.F., 1984, Process Geomorphology: W.C. Brown Co., Debuque, Iowa, 603 p.

Shearman, J.O., 1990, User's manual for WSPRO--a computer model for water surface profile computations: Federal Highway Administration Publication FHWA-IP-89-027, 187 p.

Shearman, J.O., Kirby, W.H., Schneider, V.R., and Flippo, H.N., 1986, Bridge waterways analysis model; research report: Federal Highway Administration Publication FHWA-RD-86-108, 112 p.

Talbot, A.N., 1887, The determination of water-way for bridges and culverts.

U.S. Department of Transportation, 1993, Stream stability and scour at highway bridges, Participant Workbook: Federal Highway Administration Publication FHWA HI-91-011.

U.S. Geological Survey, 1954, Stamford, Vermont 7.5 Minute Series quadrangle map: U.S. Geological Survey Topographic Maps, Scale 1:24,000. 


\section{APPENDIX A: \\ WSPRO INPUT FILE}




\section{WSPRO INPUT FILE}

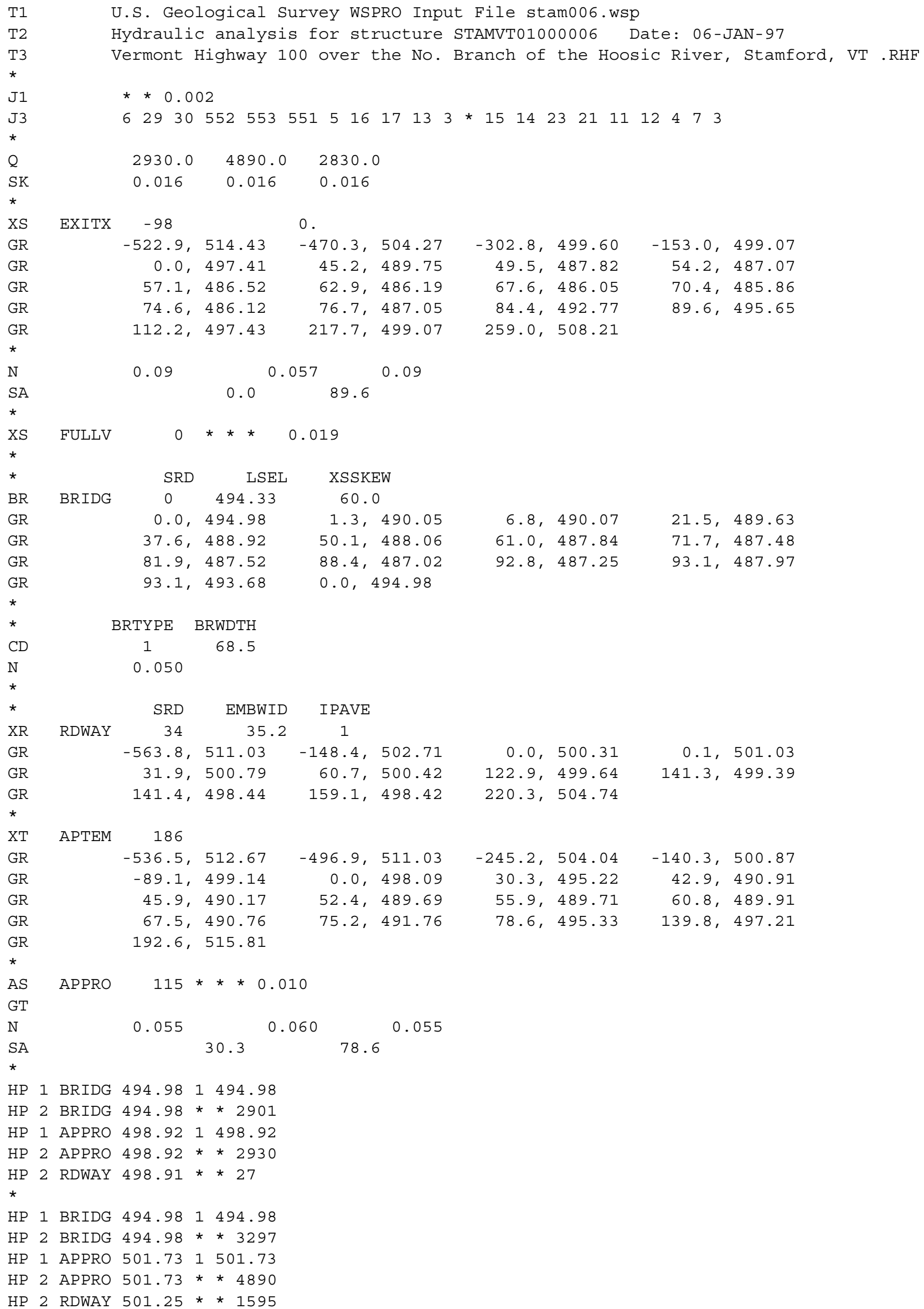




\section{APPENDIX B: \\ WSPRO OUTPUT FILE}


WSPRO OUTPUT FILE

WSPRO FEDERAL HIGHWAY ADMINISTRATION - U. S. GEOLOGICAL SURVEY

V090192 MODEL FOR WATER-SURFACE PROFILE COMPUTATIONS

U.S. Geological Survey WSPRO Input File stam006.wsp

Hydraulic analysis for structure STAMVT01000006 Date: 06-JAN-97

Vermont Highway 100 over the No. Branch of the Hoosic River, Stamford, VT $\star \star \star$ RUN DATE \& TIME: 02-11-97 07:50

CROSS-SECTION PROPERTIES: ISEQ $=3 ;$ SECID = BRIDG; $\quad$ SRD $=0$.

$\begin{array}{rrrrrrrrrr}\text { WSEL } & \text { SA\# } & \text { AREA } & \text { K } & \text { TOPW } & \text { WETP } & \text { ALPH } & \text { LEW } & \text { REW } & \text { QCR } \\ & 1 & 268 . & 15031 . & 0 . & 104 . & & & & 0 . \\ 494.98 & & 268 . & 15031 . & 0 . & 104 . & 1.00 & 0 . & 93 . & 0 .\end{array}$

VELOCITY DISTRIBUTION: ISEQ $=3 ; \quad \mathrm{SECID}=\mathrm{BRIDG} ; \quad \mathrm{SRD}=\quad 0$.

$\begin{array}{lllll}\text { WSEL } & \text { LEW } & \text { REW } & \text { AREA } & \text { K } \\ 494.98 & & \end{array}$

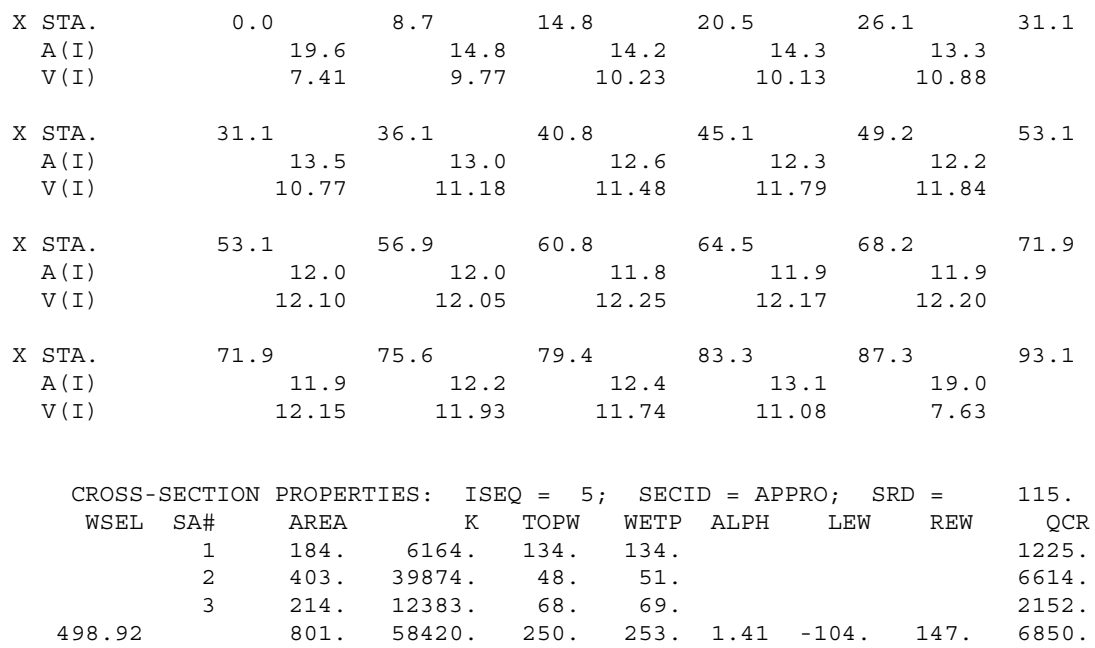

VELOCITY DISTRIBUTION: ISEQ $=5 ;$ SECID $=$ APPRO; $\quad$ SRD $=115$.

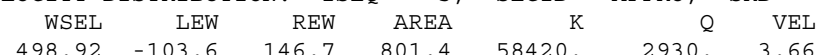

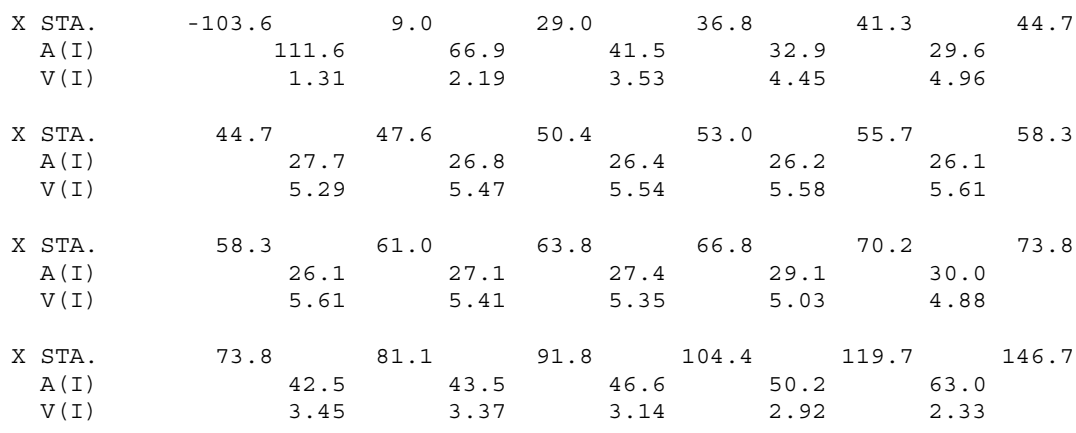

VELOCITY DISTRIBUTION: ISEQ $=4 ; \quad \operatorname{SECID~=~RDWAY;~} \quad \mathrm{SRD}=34$. $\begin{array}{rrrrrrr}\text { WSEL } & \text { LEW } & \text { REW } & \text { AREA } & \text { K } & \text { Q } & \text { VEL } \\ 498.91 & 141.4 & 163.8 & 9.7 & 90 . & 27 . & 2.79\end{array}$

\begin{tabular}{|c|c|c|c|c|c|c|c|}
\hline \multirow[t]{3}{*}{$\mathrm{x}$} & STA. & 141.4 & 142.6 & 143.5 & 144.5 & 145.5 & 146.4 \\
\hline & $A(I)$ & \multirow{2}{*}{$\begin{array}{r}0.6 \\
2.41\end{array}$} & 0.5 & 0.5 & 0.5 & \multicolumn{2}{|c|}{0.4} \\
\hline & $V(I)$ & & 2.97 & 2.94 & 3.00 & \multicolumn{2}{|c|}{3.01} \\
\hline \multirow[t]{3}{*}{$\mathrm{X}$} & STA. & 146.4 & 147.3 & 148.3 & 149.2 & 150.1 & 151.1 \\
\hline & $\mathrm{A}(\mathrm{I})$ & 0.5 & 0.4 & 0.4 & 0.4 & \multicolumn{2}{|c|}{0.4} \\
\hline & $V(I)$ & 2.98 & 3.04 & 3.01 & 3.04 & \multicolumn{2}{|c|}{3.03} \\
\hline \multirow[t]{3}{*}{$\mathrm{X}$} & STA. & 151.1 & 152.0 & 152.9 & 153.9 & 154.8 & 155.8 \\
\hline & $A(I)$ & 0.4 & 0.4 & 0.5 & 0.5 & \multicolumn{2}{|c|}{0.5} \\
\hline & $V(I)$ & 3.02 & 3.01 & 2.97 & 2.99 & \multicolumn{2}{|c|}{2.92} \\
\hline \multirow[t]{3}{*}{$\mathrm{s}$} & STA. & 155.8 & 156.7 & 157.7 & 158.7 & 159.9 & 163.8 \\
\hline & $A(I)$ & 0.5 & 0.5 & 0.5 & 0.6 & \multicolumn{2}{|c|}{0.8} \\
\hline & $\mathrm{V}(\mathrm{I})$ & 2.93 & 2.82 & 2.73 & 2.42 & & \\
\hline
\end{tabular}


WSPRO OUTPUT FILE (continued)

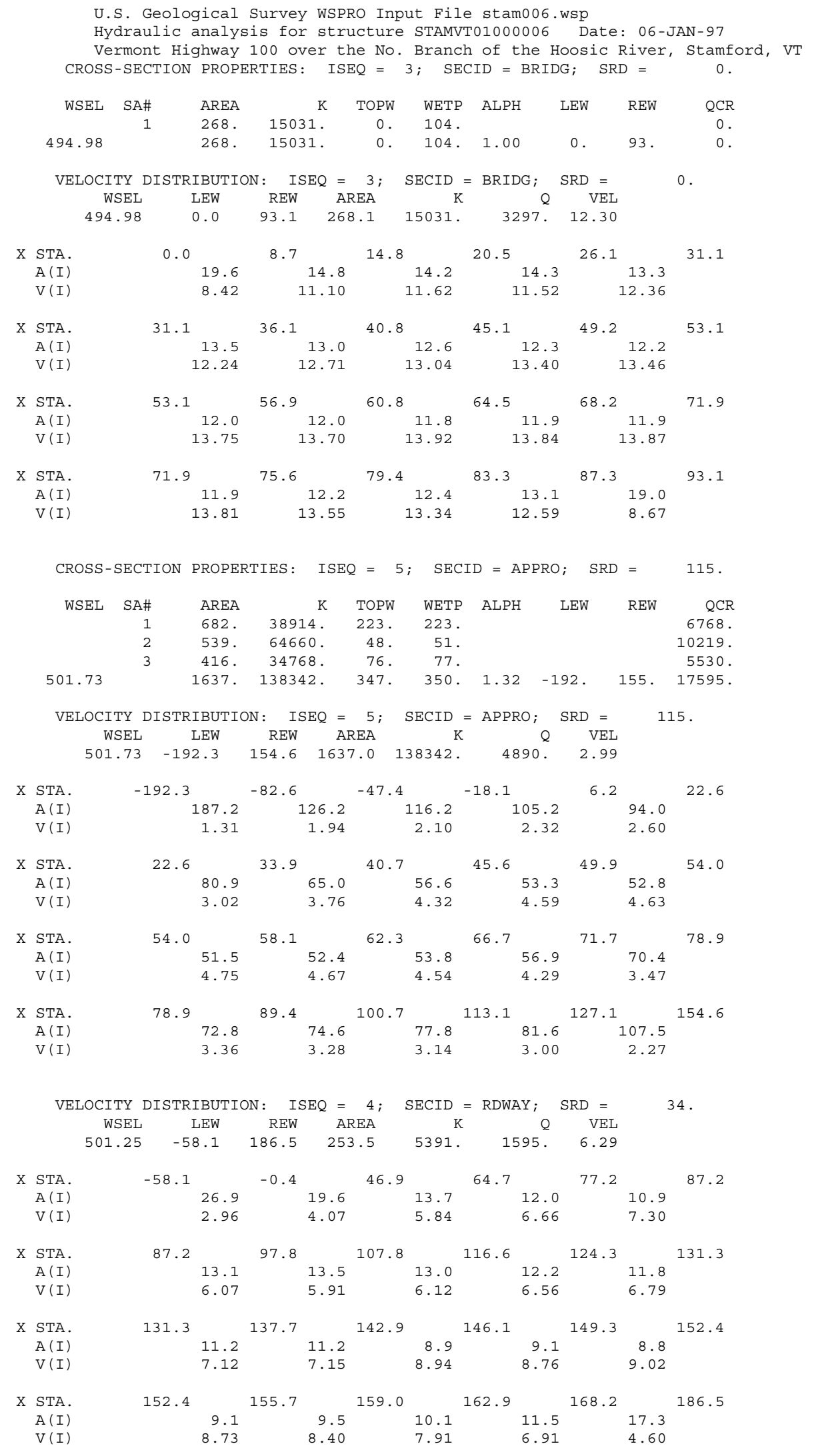


WSPRO OUTPUT FILE (continued)

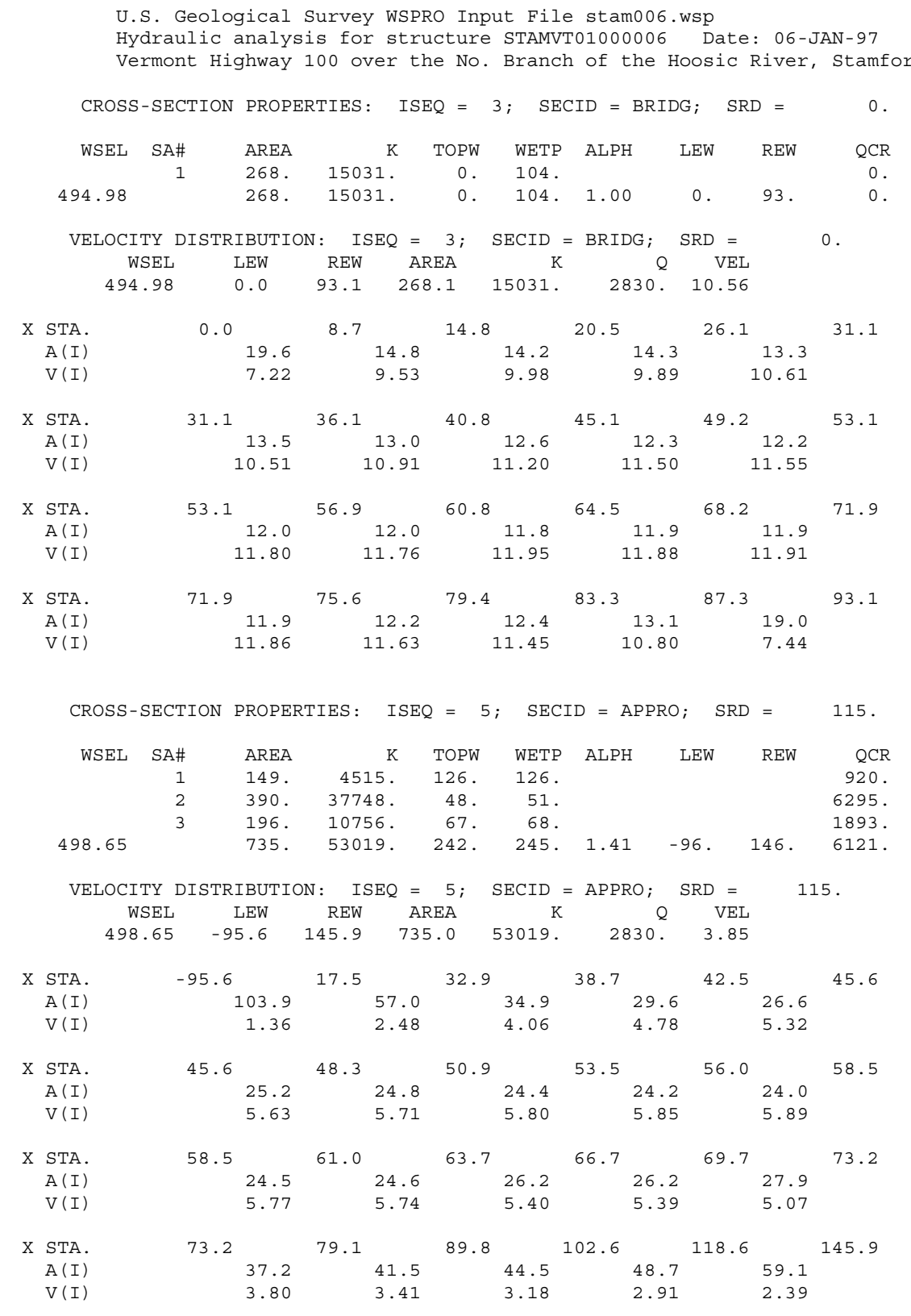


WSPRO OUTPUT FILE (continued)

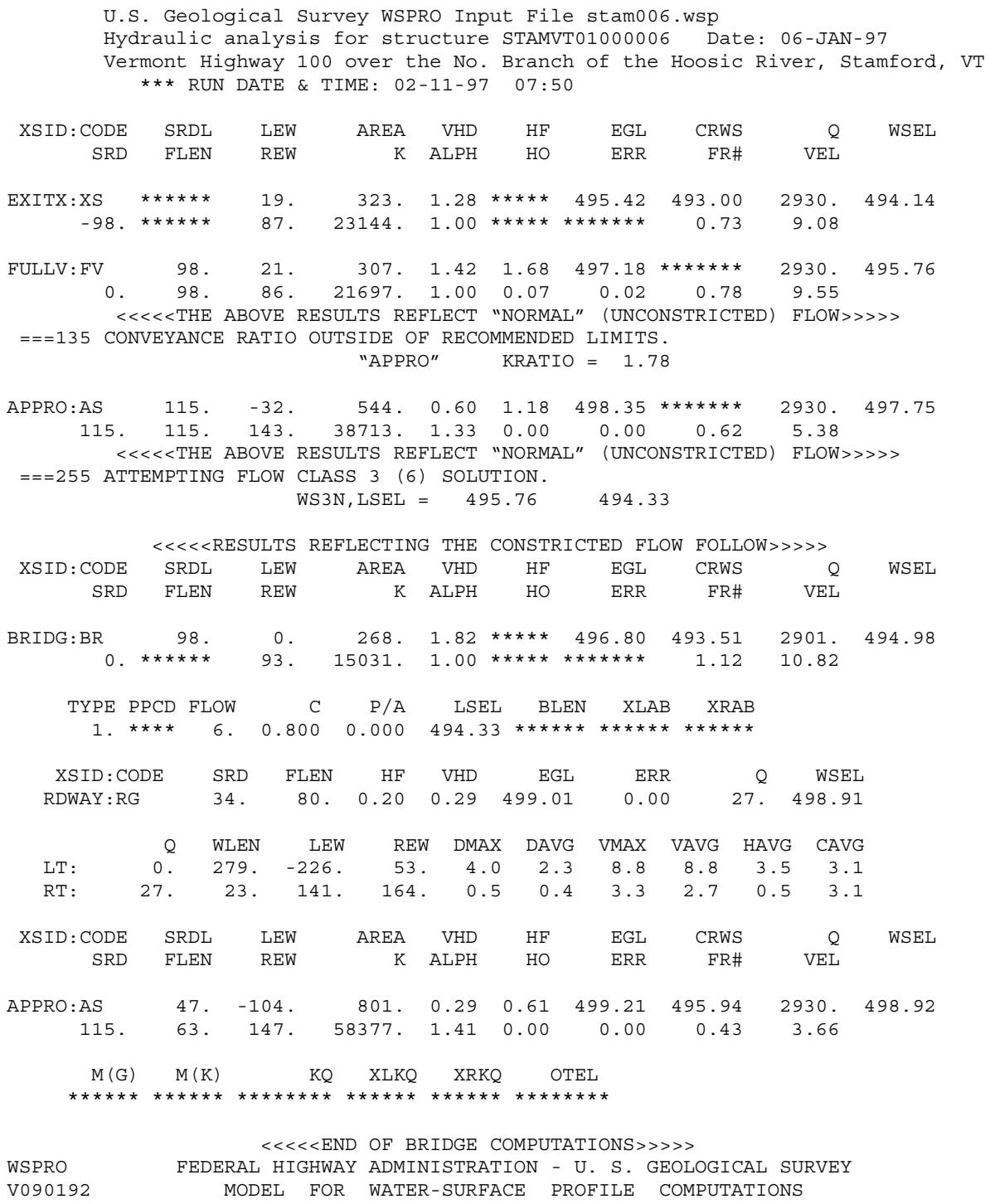

$\begin{array}{lrrrrrrrrr}\text { XSID :CODE } & \text { CRWS } & \text { FR\# } & \text { YMIN } & \text { YMAX } & \text { HF } & \text { HO } & \text { VHD } & \text { EGL } & \text { WSEL } \\ \text { EXITX:XS } & 493.00 & 0.73 & 485.86 & 514.43 * * * * * * * * * * & 1.28 & 495.42 & 494.14 \\ \text { FULLV:FV } & * * * * * * * * & 0.78 & 487.72 & 516.29 & 1.68 & 0.07 & 1.42 & 497.18 & 495.76 \\ \text { BRIDG :BR } & 493.51 & 1.12 & 487.02 & 494.98 * * * * * * * * * * * & 1.82 & 496.80 & 494.98 \\ \text { RDWAY:RG } & * * * * * * * * * * * * * * * * & 498.42 & 511.03 & 0.20 * * * * * * & 0.29 & 499.01 & 498.91 \\ \text { APPRO:AS } & 495.94 & 0.43 & 488.98 & 515.10 & 0.61 & 0.00 & 0.29 & 499.21 & 498.92\end{array}$


WSPRO OUTPUT FILE (continued)

WSPRO FEDERAL HIGHWAY ADMINISTRATION - U. S. GEOLOGICAL SURVEY

U.S. Geological Survey WSPRO Input File stam006.wsp

Hydraulic analysis for structure STAMVT01000006 Date: 06-JAN-97

Vermont Highway 100 over the No. Branch of the Hoosic River, Stamford, VT *** RUN DATE \& TIME: 02-11-97 07:50

\begin{tabular}{|c|c|c|c|c|c|c|c|c|c|c|}
\hline XSID:C & ODE & SRDL & LEW & AREA & VHD & $\mathrm{HF}$ & EGL & CRWS & Q & WSEL \\
\hline & SRD & FLEN & REW & $\mathrm{K}$ & ALPH & $\mathrm{HO}$ & ERR & FR\# & VEL & \\
\hline EXITX:X & & $\star \star \star \star * \star *$ & 7. & 476. & 1.65 & 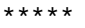 & 497.80 & 494.95 & 4890 . & 496.15 \\
\hline & 98. & 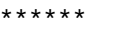 & 96. & 38656 . & 1.01 & $\star \star \star \star \star *$ & 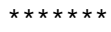 & 0.78 & 10.28 & \\
\hline$===125$ & FR\# & $\begin{array}{r}\text { EXCEEDS } \\
\text { FNTEST }\end{array}$ & $\begin{array}{l}\text { FNTEST } \\
\text { T, FR\#, Ws }\end{array}$ & $\begin{array}{l}\text { AT SECID } \\
\text { SEL, CRWS }\end{array}$ & $\begin{array}{r}\text { "FULL } \\
=0.8\end{array}$ & $\begin{array}{l}\text { "LV": } \\
80\end{array}$ & $\begin{array}{l}\text { TRIALS } \\
0.82\end{array}$ & $\begin{array}{c}\text { CONTINUED } \\
497.76\end{array}$ & 496.8 & \\
\hline$===110$ & WSEI & L NOT FOL & $\begin{array}{l}\text { UND AT } \\
\text { WSLIM1, }\end{array}$ & $\begin{array}{l}\text { SECID "FU1 } \\
\text { WSLIM2, DEI }\end{array}$ & $\begin{array}{l}\text { JLLV" : } \\
\text { SLTAY = }\end{array}$ & $=\begin{array}{r}\text { REDL } \\
=\quad 49\end{array}$ & $\begin{array}{l}\text { UCED DEL } \\
95.65\end{array}$ & $\begin{array}{l}\text { UTAY. } \\
\quad 516.29\end{array}$ & 0.50 & \\
\hline$===115$ & WSEI & L NOT FOL & $\begin{array}{l}\text { UND AT } \\
\text { WSLIM1, }\end{array}$ & $\begin{array}{l}\text { SECID "FU1 } \\
\text { WSLIM2, CRI }\end{array}$ & $\begin{array}{l}\text { JLLV" : } \\
\text { RWS = }\end{array}$ & $\begin{array}{l}\text { USEI } \\
495 \text {. }\end{array}$ & $\begin{array}{l}\text { D WSMIN } \\
.65\end{array}$ & $\begin{array}{l}=\text { CRWS } \\
516.29\end{array}$ & 496.81 & \\
\hline
\end{tabular}

$\begin{array}{lllllllllll}\text { FULLV }: F V & 98 . & 9 & 9 & 453 . & 1.82 & 1.68 & 499.56 & 496.81 & 4890 . & 497.74\end{array}$ 0.98. 93. 36167. $1.00 \quad 0.08 \quad 0.00 \quad 0.82 \quad 10.81$

$<<<<$ THE ABOVE RESULTS REFLECT "NORMAL" (UNCONSTRICTED) FLOW $>>>>>$ $===135$ CONVEYANCE RATIO OUTSIDE OF RECOMMENDED LIMITS .

"APPRO" KRATIO $=2.35$

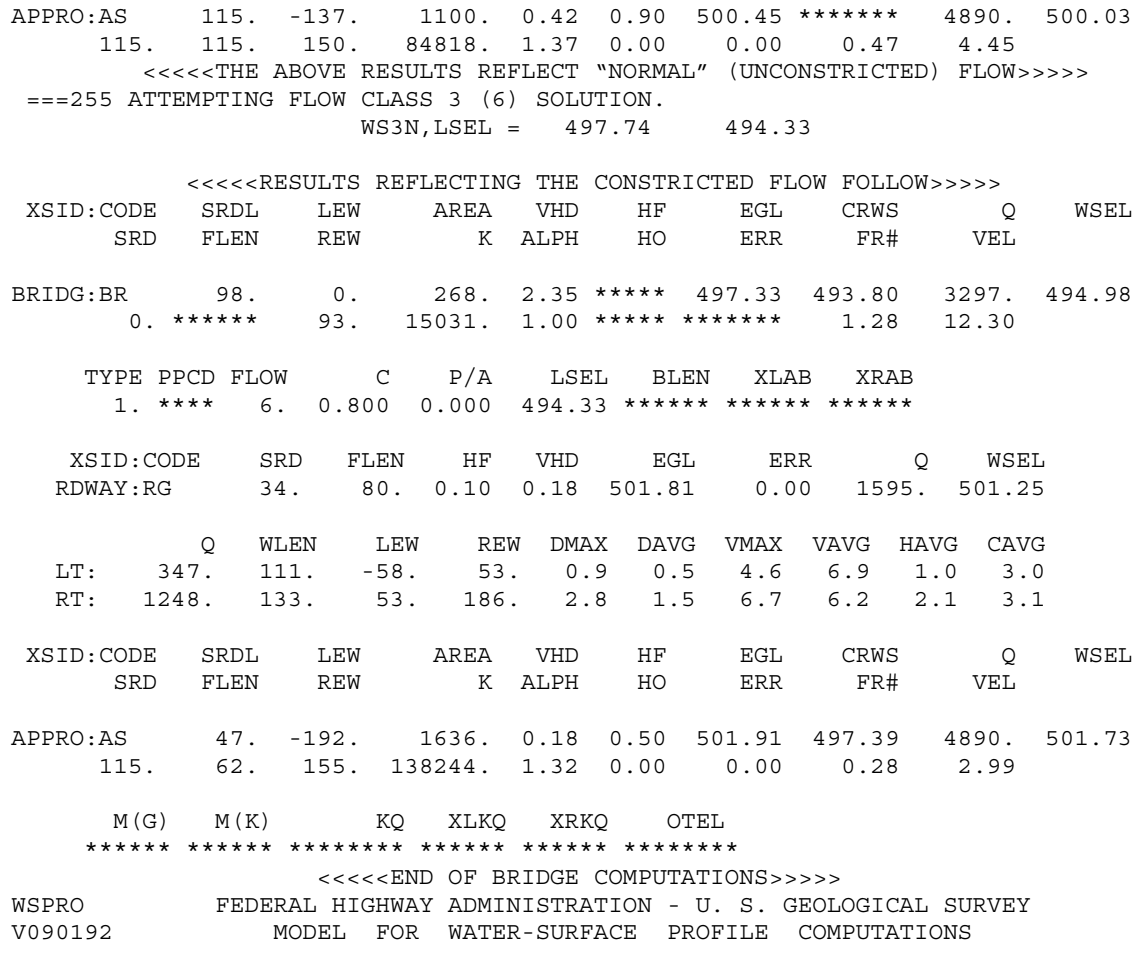

$\begin{array}{lcrrrrrrrr}\text { XSID : CODE } & \text { CRWS } & \text { FR\# } & \text { YMIN } & \text { YMAX } & \text { HF } & \text { HO } & \text { VHD } & \text { EGL } & \text { WSEL } \\ \text { EXITX:XS } & 494.95 & 0.78 & 485.86 & 514.43 * * * * * * * * * * * & 1.65 & 497.80 & 496.15 \\ \text { FULLV :FV } & 496.81 & 0.82 & 487.72 & 516.29 & 1.68 & 0.08 & 1.82 & 499.56 & 497.74 \\ \text { BRIDG : BR } & 493.80 & 1.28 & 487.02 & 494.98 * * * * * * * * * * * & 2.35 & 497.33 & 494.98 \\ \text { RDWAY: RG } & * * * * * * * * * * * * * * * * & 498.42 & 511.03 & 0.10 * * * * * * & 0.18 & 501.81 & 501.25 \\ \text { APPRO:AS } & 497.39 & 0.28 & 488.98 & 515.10 & 0.50 & 0.00 & 0.18 & 501.91 & 501.73\end{array}$


WSPRO OUTPUT FILE (continued)

WSPRO

V090192
FEDERAL HIGHWAY ADMINISTRATION - U. S. GEOLOGICAL SURVEY

MODEL FOR WATER-SURFACE PROFILE COMPUTATIONS

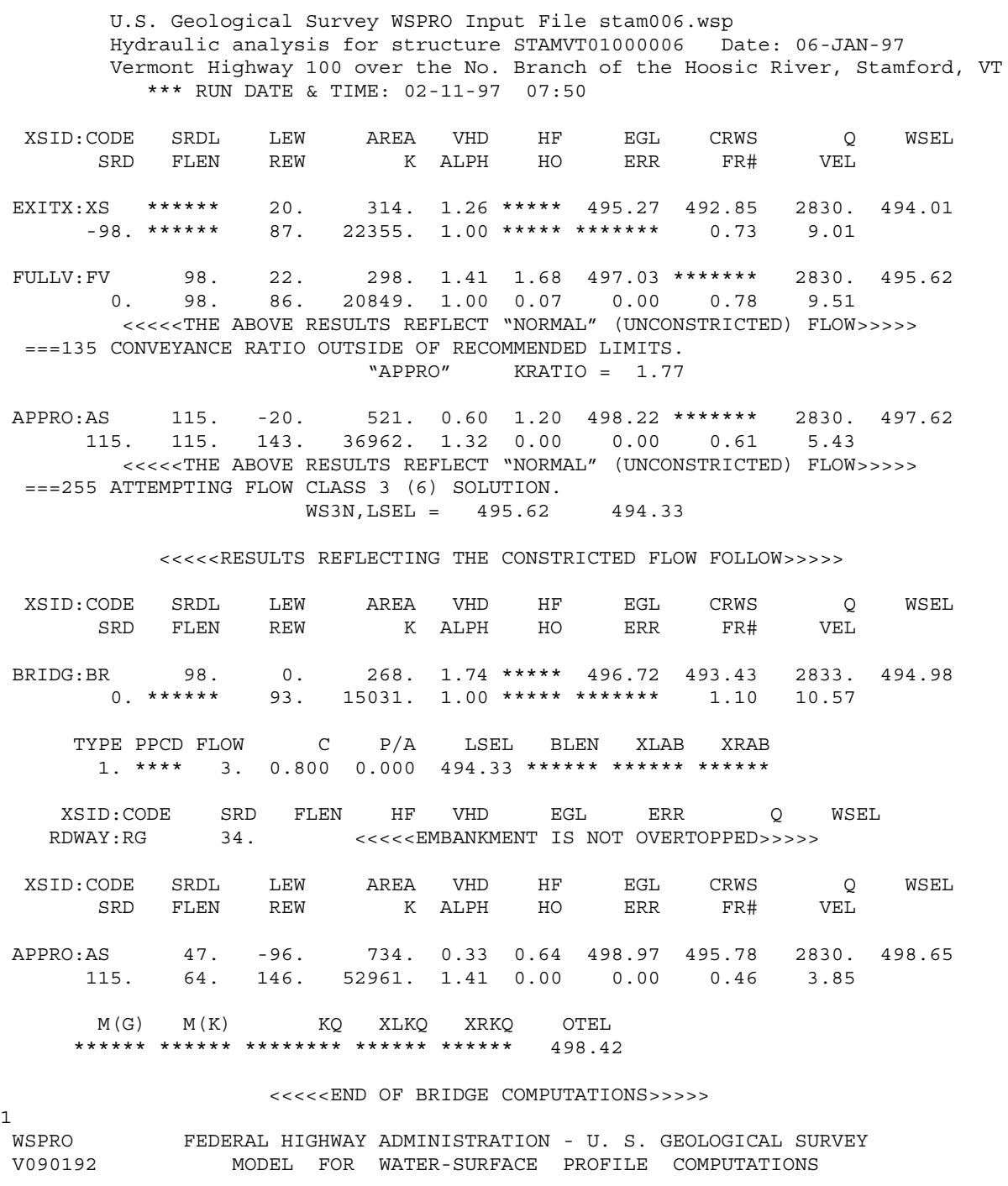




\section{APPENDIX C:}

\section{BED-MATERIAL PARTICAL-SIZE DISTRIBUTION}




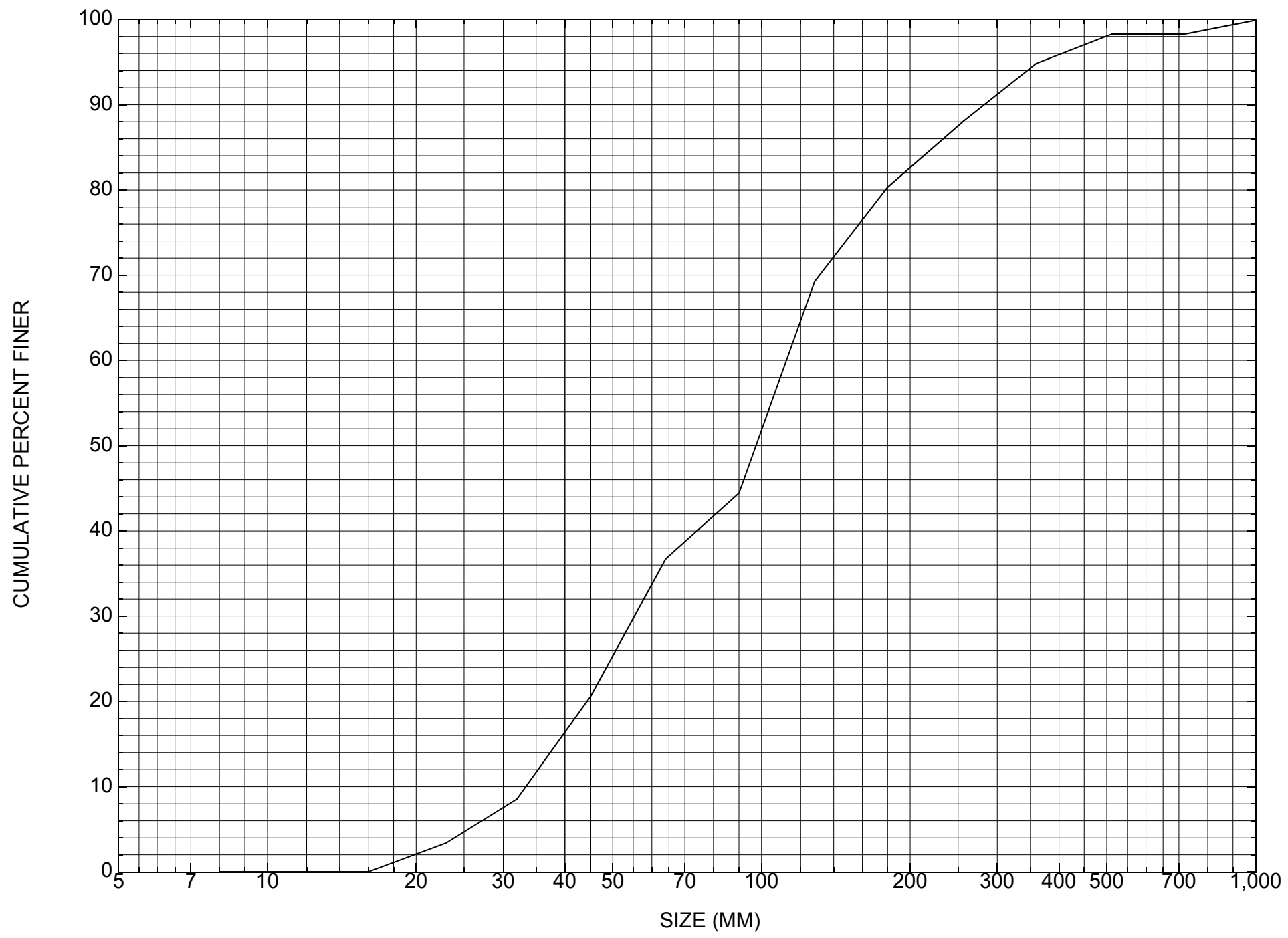

Appendix C. Bed material particle-size distribution for a pebble count in the channel approach of structure STAMVT01000006, in Stamford, Vermont. 


\section{APPENDIX D: \\ HISTORICAL DATA FORM}




\section{Structure Number STAMVT01000006}

\section{General Location Descriptive}

Data collected by (First Initial, Full last name) $\underline{\mathbf{L}}$. Medalie

Date $(M M / D D / Y Y) \_09 / \underline{28} / \underline{95}$

Highway District Number (I - 2; nn) 01

Town (FIPS place code; I - 4; nnnnn) $\mathbf{6 9 7 7 5}$

Waterway (I - 6) NO. BR. HOOSIC RIVER

Route Number VT100

Topographic Map Stamford

Latitude (I - 16; nnnn.n) $\mathbf{4 2 4 6 4}$
County (FIPS county code; I - 3; nnn)

Mile marker (I - 11; nnn.nnn) $\underline{\mathbf{0 0 2 8 5 0}}$

Road Name (I - 7): -

Vicinity (I - 9) 2.8 MI N MA STATE LINE

Hydrologic Unit Code: -

Longitude (i - 17; nnnnn.n) 73031

\section{Select Federal Inventory Codes}

FHWA Structure Number (I - 8) $\mathbf{2 0 0 1 0 2 0 0 0 6 0 2 1 4}$

Maintenance responsibility $(I-21 ; n n) \quad \mathbf{0 1} \quad$ Maximum span length $(I-48 ; n n n n) \underline{\mathbf{0 0 9 7}}$

Year built (I - 27; YYYY) 1963

Structure length (I - 49; nnnnnn) $\underline{000099}$

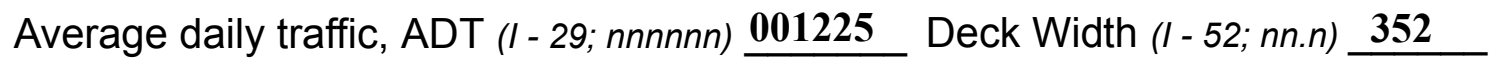

Year of ADT (I-30; YY) $\mathbf{9 2}$

Channel \& Protection $(I-61 ; n) \underline{6}$

Opening skew to Roadway $(I-34 ; n n) \quad \mathbf{6 0}$

Waterway adequacy $(I-71 ; n) \quad 5$

Operational status $(I-41 ; X) \quad \mathbf{A}$

Underwater Inspection Frequency $(I-92 B ; X Y Y) \_\mathbf{N}$

Structure type (I- 43; nnn) $\mathbf{3 0 2}$

Year Reconstructed (I - 106) $\mathbf{0 0 0 0}$

Approach span structure type (I - 44; nnn) $\mathbf{0 0 0}$

Clear span $(n n n . n f t) \quad 45$

Number of spans (I - 45; nnn) $\underline{\mathbf{0 0 1}}$

Vertical clearance from streambed (nnn.n ft) $\underline{\mathbf{7 . 3}}$

Number of approach spans (I- 46; nnnn) $\underline{\mathbf{0 0 0 0}}$ Waterway of full opening $\left(n n n . n \mathrm{ft}^{2}\right) \underline{\mathbf{3 2 8 . 5}}$

Comments:

According to the structural inspection report dated $8 / 23 / 93$, structure is a single span rolled beam bridge. Channel is straight through the structure; flow is toward Labut side of channel. Some minor scour noted along Rabut but no undermining. Some minor stream bank erosion at US Labut. A buildup of stone and gravel along Rabut side of channel on US end of structure is noted. Stem of Rabut has some minor stain ing, cracking, and scaling down along the flow line. Stem of Labut has some cracking with leakage at the fascias. Remainder of the stem has some minor cracking, staining, and scaling along the flow line. Labut wings have some minor cracking with leakage. Footings not exposed. 


\section{Bridge Hydrologic Data}

Is there hydrologic data available? $\underline{\mathbf{Y}}$ if No, type ctrl- $h \quad$ VTAOT Drainage area $\left(m i^{2}\right): \underline{\mathbf{8 . 8}}$

Terrain character:

Stream character \& type: -

Streambed material:

Discharge Data (cfs):

$$
\mathrm{Q}_{2.33} \frac{\mathbf{8 8 0}}{\mathbf{2 6 1 0}}
$$

Record flood date ( $M M / D D / Y Y)$ : I

Estimated Discharge (cfs): Ice conditions (Heavy, Moderate, Light) : -

$Q_{10} \frac{\mathbf{1 4 7 0}}{\mathbf{2 9 8 0}}$

$\mathrm{Q}_{25} \lcm{2110}$

$\mathrm{Q}_{500}$

Water surface elevation $(f t):-$

The stage increases to maximum highwater elevation (Rapidly, Not rapidly):

The stream response is (Flashy, Not flashy):

Describe any significant site conditions upstream or downstream that may influence the stream's stage: -

Watershed storage area (in percent): ${ }_{-} \quad \%$

The watershed storage area is: - _ (1-mainly at the headwaters; 2- uniformly distributed; 3-immediatly upstream oi the site)

Water Surface Elevation Estimates for Existing Structure:

\begin{tabular}{|l|l|c|c|l|l|}
\hline Peak discharge frequency & $Q_{2.33}$ & $Q_{10}$ & $Q_{25}$ & $Q_{50}$ & $Q_{100}$ \\
Water surface elevation (ft)) & $\mathbf{1 2 1 2 . 6}$ & $\mathbf{1 2 1 3 . 6}$ & $\mathbf{1 2 1 4 . 1}$ & $\mathbf{1 2 1 4 . 5}$ & $\mathbf{1 2 1 5 . 2}$ \\
Velocity $(\mathrm{ft} / \mathrm{sec})$ & - & - & - & - & - \\
\hline
\end{tabular}

Long term stream bed changes: -

Is the roadway overtopped below the $Q_{100}$ ? (Yes, No, Unknown):

Frequency: -

Relief Elevation $(f t)$ :

Discharge over roadway at $Q_{100}\left(f^{3} / \mathrm{sec}\right)$ :

Are there other structures nearby? (Yes, No, Unknown): $\mathbf{y}$ Upstream distance (miles): Town: If No or Unknown, type ctrl-n os Highway No. : VT100 Structure No. : 8 Year Built: 1963 Clear span (ft): $\mathbf{3 4 . 8}$ Clear Height $(f t): \underline{6}$ Full Waterway $\left(t^{2}\right)$ : 208.8 
Downstream distance (miles): Town: Stamford

Highway No. : $\underline{\text { TH } 1}$ Structure No. : 7 Structure Type: I-BEAM, STRINGER

Clear span $(f t): \underline{43}$ Clear Height $(f t): \underline{\mathbf{8}}$ Full Waterway $\left(t^{2}\right):$

Comments:

Water surface elevations above based on channel bottom elevation 1207.2' at approach. Data from FEMA study. Design flow Q50. Recommendation from study that the existing bridge appears inadequate hydraulically. New structure with at least 50' clear span and minimum clear height of 8' is recommended.

\section{USGS Watershed Data}

Watershed Hydrographic Data

Drainage area (DA) $\mathbf{8 . 6}$

Watershed storage (ST)

Bridge site elevation 1217 $\mathrm{mi}^{2}$ Lake and pond area 0.35 $\mathrm{mi}^{2}$

Main channel length 3.98 $\mathrm{ft}$ $\%$

$10 \%$ channel length elevation mi

Headwater elevation 2970 $\mathrm{ft}$

Main channel slope (S)

(S) 345.1 $\mathrm{ft} \quad 85 \%$ channel length elevation

2230 $\mathrm{ft}$

Watershed Precipitation Data

Average site precipitation in Average headwater precipitation in

Maximum 2yr-24hr precipitation event $(124,2)$ in

Average seasonal snowfall (Sn) $\mathrm{ft}$ 


\section{Bridge Plan Data}

Are plans available? $\underline{\mathbf{Y}}$ Project Number
If no, type ctrl-n pl

Date issued for construction ( $M M / Y Y Y Y$ ):

\section{Low superstructure elevation: USLAB $\underline{\mathbf{1 2 1 3 . 6 9}}$ \\ DSLAB 1212.41 \\ Benchmark location description:}

Minimum channel bed elevation:

1211.30

New bridge disc elev. 1219.10 on downstream right corner post end.

Reference Point (MSL, Arbitrary, Other):

Datum (NAD27, NAD83, Other): Unknown

Foundation Type:

(1-Spreadfooting; 2-Pile; 3- Gravity; 4-Unknown)

If 1 : Footing Thickness 1 Footing bottom elevation: $\underline{\mathbf{2}}$

If 2: Pile Type: 12 (1-Wood; 2-Steel or metal; 3-Concrete) Approximate pile driven length: 01

If 3: Footing bottom elevation:

Is boring information available? If no, type ctrl-n bi Number of borings taken:

Foundation Material Type: $\mathbf{Y}$ (1-regolith, 2-bedrock, 3-unknown)

Briefly describe material at foundation bottom elevation or around piles:

5

3

Rabut foundation in refusal (bedrock?)

Labut foundation in hard sand and gravel

Comments:

Right footing bottom elev = 1201'; left footing bottom elev $=1202.5$ '.

The low superstructure elevations are the bridge seat elevations from the bridge plans. 


\section{Cross-sectional Data}

Is cross-sectional data available? If no, type ctrl-n xs

Source (FEMA, VTAOT, Other)?

Comments: $Y$

\section{FEMA}

\begin{tabular}{|l|l|l|l|l|l|l|l|l|l|l|l|}
\hline Station & Sta- & mea- & & $\mathbf{6 . 6}$ & 7 & 5 & 5.5 & - & - & - & - \\
\hline Feature & tion & sure- & $\mathbf{1 7 5}$ & $\mathbf{1 7 9}$ & $\mathbf{2 3 5}$ & $\mathbf{2 7 6}$ & $\mathbf{7}$ & - & - & - & - \\
\hline $\begin{array}{l}\text { Low cord } \\
\text { elevation }\end{array}$ & and & ments & LAB & - & - & RAB & - & - & - & - & - \\
\hline $\begin{array}{l}\text { Bed } \\
\text { elevation }\end{array}$ & eleva- & are in & $\mathbf{1 2 1 3 . 6}$ & $\mathbf{1 2 1 3 . 5}$ & $\mathbf{1 2 1 3}$ & $\mathbf{1 2 1 2}$. & - & - & - & - & - \\
\hline $\begin{array}{l}\text { Low cord to } \\
\text { bed length }\end{array}$ & tion & feet. & $\mathbf{1 2 0 7}$ & $\mathbf{1 2 0 6 . 5}$ & $\mathbf{1 2 0 8}$ & $\mathbf{5 1 2 0}$ & - & - & - & - & - \\
\hline Station & - & - & - & - & - & - & - & - & - & - & - \\
\hline Feature & - & - & - & - & - & - & - & - & - & - & - \\
\hline $\begin{array}{l}\text { Low cord } \\
\text { elevation }\end{array}$ & - & - & - & - & - & - & - & - & - & - & - \\
\hline $\begin{array}{l}\text { Bed } \\
\text { elevation }\end{array}$ & - & - & - & - & - & - & - & - & - & - & - \\
\hline $\begin{array}{l}\text { Low cord to } \\
\text { bed length }\end{array}$ & - & - & - & - & - & - & - & - & - & - & - \\
\hline
\end{tabular}

Source (FEMA, VTAOT, Other)?

Comments: -

\begin{tabular}{|l|l|l|l|l|l|l|l|l|l|l|l|}
\hline Station & - & - & OT & vatio & toco & VTA & data & - & - & - & - \\
\hline Feature & - & - & Brid & ns & pies & OT & is & - & - & - & - \\
\hline $\begin{array}{l}\text { Low cord } \\
\text { elevation }\end{array}$ & - & - & ge & are & of & cross & avail & - & - & - & - \\
\hline $\begin{array}{l}\text { Bed } \\
\text { elevation }\end{array}$ & - & - & seat & on & plan & -sec- & able. & - & - & - & - \\
\hline $\begin{array}{l}\text { Low cord to } \\
\text { bed length }\end{array}$ & - & VTA & ele- & pho- & s. & tion & - & - & - & - & - \\
\hline Station & - & - & - & - & - & - & - & - & - & - & - \\
\hline Feature & - & - & - & - & - & - & - & - & - & - & - \\
\hline $\begin{array}{l}\text { Low cord } \\
\text { elevation }\end{array}$ & - & - & - & - & - & - & - & - & - & - & - \\
\hline $\begin{array}{l}\text { Bed } \\
\text { elevation }\end{array}$ & - & - & - & - & - & - & - & - & - & - & - \\
\hline $\begin{array}{l}\text { Low cord to } \\
\text { bed length }\end{array}$ & - & - & - & - & - & - & - & - & - & - & - \\
\hline
\end{tabular}




\section{APPENDIX E: \\ LEVEL I DATA FORM}


U. S. Geological Survey

Bridge Field Data Collection and Processing Form

Qa/Qc Check by: $\underline{\mathbf{R B}}$ Date: $10 / 07 / 96$

\section{Structure Number STAMVT01000006}

\section{A. General Location Descriptive}

1. Data collected by (First Initial, Full last name) $\mathbf{R}$. FLYNN

2. Highway District Number $\mathbf{0 1}$

Mile marker $\underline{\mathbf{0 0 2 8 5 0}}$

County 003

Waterway $(I$ - 6) N. BRANCH HOOSIC RIVER

Route Number VT 100

Town 69775

Road Name VT 100

Hydrologic Unit Code: -

3. Descriptive comments:

Located 2.8 miles north of the Massachusetts state line.

\section{B. Bridge Deck Observations}
4. Surface cover... LBUS 6
RBUS 6
LBDS 4
RBDS 6
Overall 6

(2b us, ds,lb,rb: 1- Urban; 2- Suburban; 3- Row crops; 4- Pasture; 5- Shrub- and brushland; 6- Forest; 7- Wetland)
5. Ambient water surface... US 1
UB 2
DS 2
(1- pool; 2- riffle)

6. Bridge structure type 1 (1- single span; 2- multiple span; 3- single arch; 4- multiple arch; 5-cylindrical culvert; 6- box culvert; or 7- other)
7. Bridge length 99
(feet)
Span length 97
(feet)
Bridge width 35.2 (feet)

\section{Road approach to bridge:}
8. LB 0 RB 0
( 0 even, 1- lower, 2- higher)
9. LB 1 RB 1
(1- Paved, 2- Not paved)

10. Embankment slope (run / rise in feet / foot)

$$
\text { US left }
$$

0.0:1

US right

0.0:1

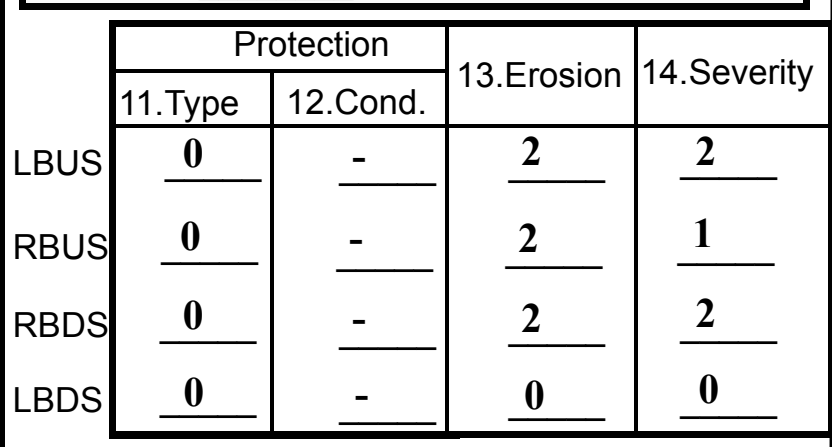

Bank protection types: 0- none; 1- $<12$ inches;

2- < 36 inches; 3- < 48 inches;

4- < 60 inches; 5- wall / artificial levee

Bank protection conditions: 1- good; 2- slumped;

3- eroded; 4- failed

Erosion: 0 - none; 1- channel erosion; 2 -

road wash; 3- both; 4- other

Erosion Severity: 0 - none; 1- slight; 2- moderate; 3- severe

\section{Channel approach to bridge (BF):}

15. Angle of approach: $\mathbf{5}$

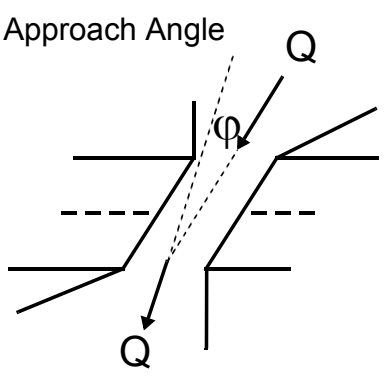

17. Channel impact zone 1 :

Where? RB (LB, RB)

Range? 0 feet US

Channel impact zone 2:

Where? $(L B, R B)$

Range? - $\quad$ feet -

(US, UB, DS) to Impact Severity: 0- none to very slight; 1- Slight; 2- Moderate; 3- Severe feet -

16. Bridge skew: 60

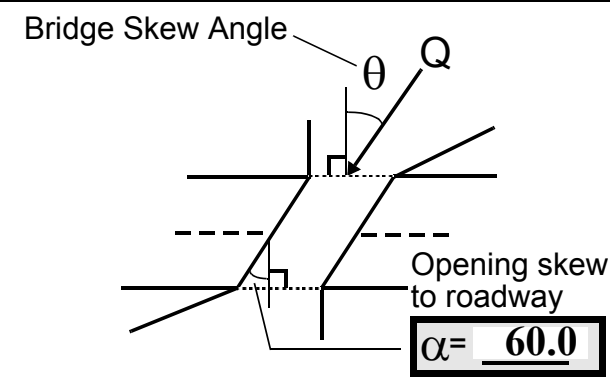

Exist? $\mathbf{Y}(Y$ or $N)$

Severity 2

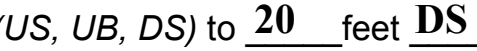

Exist? $\mathbf{N}(Y$ or $N)$

Severity - 
18. Bridge Type: $\mathbf{1 b}$

1a- Vertical abutments with wingwalls

$1 \mathrm{~b}$ - Vertical abutments without wingwalls

2- Vertical abutments and wingwalls, sloping embankment Wingwalls perpendicular to abut. face

3- Spill through abutments

4- Sloping embankment, vertical wingwalls and abutments

Wingwall angle less than $90^{\circ}$.

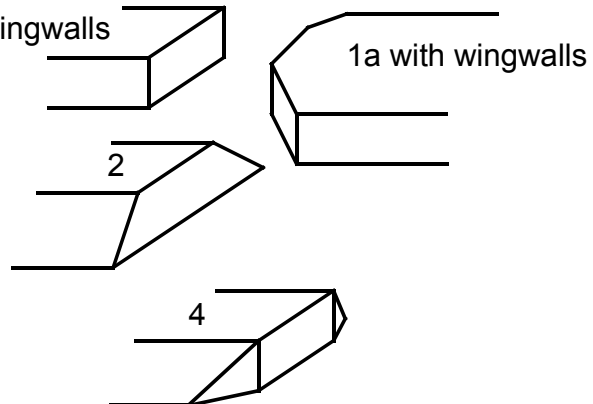

19. Bridge Deck Comments (surface cover variations, measured bridge and span lengths, bridge type variations, approach overflow width, etc.)

4. There is a house and driveway on the right bank US, but the immediate bank is a high forested hill. The left bank US is forested along the bank then it is mowed grass along VT 100. The left bank DS is a lawn with a house and barn and trees along the immediate bank. The right bank DS is forested along the bank and road embankment for VT 100.

7. Values are from the VT AOT files. Measured bridge length is $101 \mathrm{ft}$., bridge span is $91 \mathrm{ft}$., and the bridge width is $34.5 \mathrm{ft}$.

18. The sides of the abutments are parallel to VT 100 .

\section{Upstream Channel Assessment}

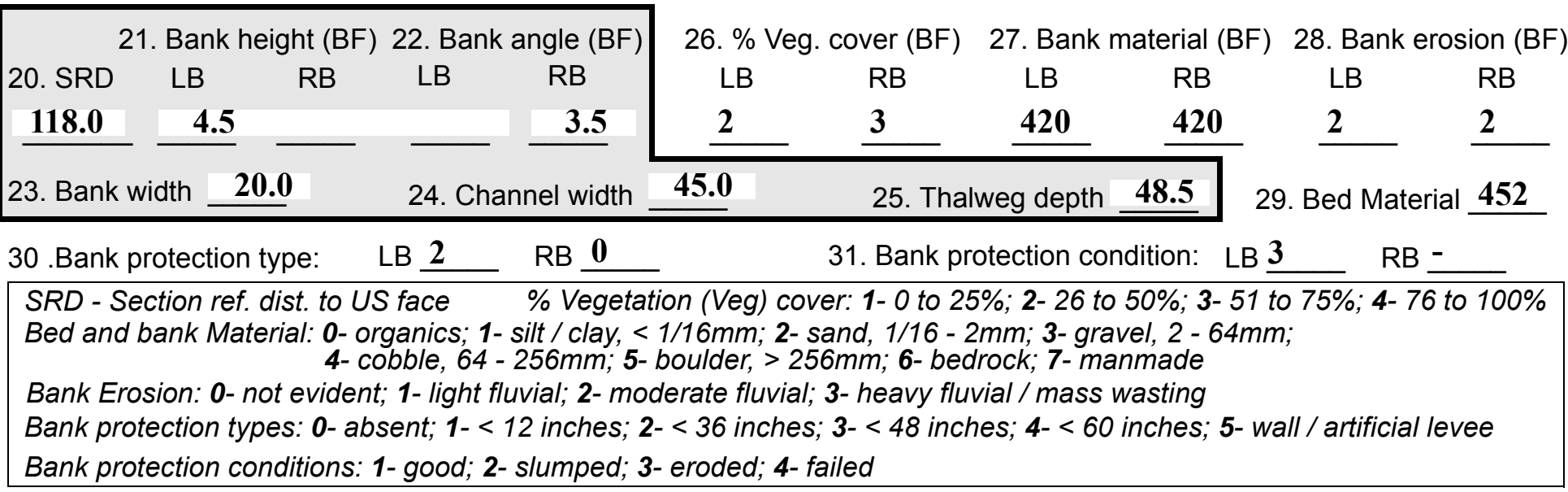

32. Comments (bank material variation, minor inflows, protection extent, etc.):

28. Both banks are scalloped and have exposed tree roots.

30. Bank protection extends from the end of the US left abutment to $150 \mathrm{ft}$. US.

There is a cobble and boulder island from $150 \mathrm{ft}$. US to $200+\mathrm{ft}$. US. It is positioned $20 \% \mathrm{LB}$ to $75 \% \mathrm{RB}$. 


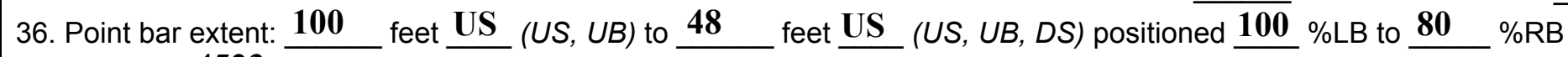

37. Material: $\underline{\mathbf{4 5 2 3}}$

38. Point or side bar comments (Circle Point or Side; Note additional bars, material variation, status, etc.):

An additional point bar is evident on the right bank from $85 \mathrm{ft}$. US to $150 \mathrm{ft}$. US. Mid-bar width is $10 \mathrm{ft}$. and it is positioned from $20 \% \mathrm{LB}$ to $\mathrm{O} \% \mathrm{RB}$. It is comprised of cobbles, boulders, sand and gravel. This point bar is below the cut bank. The bank has eroded and slumped to form the point bar.

39. Is a cut-bank present? $\mathbf{Y}$ (Y or if $N$ type ctrl-n $c b)$

41. Mid-bank distance: $\mathbf{1 1 0}$

43. Bank damage: 1

42. Cut bank extent: 80

40. Where? $\mathbf{R B} \quad(L B$ or $R B)$ feet $\underline{\mathbf{U S}}$ (US, UB) to $\underline{\mathbf{1 3 0}}$ feet $\underline{\mathbf{U S}}$ (US, UB, DS) (1- eroded and/or creep; 2- slip failure; 3- block failure)

44. Cut bank comments (eg. additional cut banks, protection condition, etc.):

Another cut bank is along the left bank from $110 \mathrm{ft}$. US to $200 \mathrm{ft}$. US. It is eroded and there are roots exposed.

45. Is channel scour present? $\mathbf{N}$ (Y or if $N$ type ctrl-n cs)

47. Scour dimensions: Length Width -

Depth : -

46. Mid-scour distance: -

48. Scour comments (eg. additional scour areas, local scouring process, etc.):

NO CHANNEL SCOUR

49. Are there major confluences? $\mathbf{N}$

51. Confluence 1: Distance Confluence 2: Distance -

NO MAJOR CONFLUENCES
( $Y$ or if $N$ type ctrl-n $m c$ )

52. Enters on -

Enters on (LB or $R B)$ ( $L B$ or $R B)$
50. How many? -

53. Type(1- perennial; 2- ephemeral)

Type (1-perennial; 2- ephemeral)

\section{Under Bridge Channel Assessment}

55. Channel restraint (BF)? LB 2

56. Height (BF)
LB RB
$\mathbf{3 2 . 5}-$
58. Bank width (BF) =
(1- natural bank; 2- abutment; 3- artificial levee)

Bed and bank Material: 0- organics; 1- silt / clay, < 1/16mm; 2- sand, 1/16 - 2mm; 3- gravel, 2 - 64mm; 4- cobble, 64 - 256mm; 5- boulder, > 256mm; 6- bedrock; 7- manmade

Bank Erosion: 0- not evident; 1- light fluvial; 2- moderate fluvial; 3- heavy fluvial / mass wasting

64. Comments (bank material variation, minor inflows, protection extent, etc.):

425

63. The stream bed is primarily cobble. The channel has a steep gradient US with a large amount of cobbles and boulders in the streambed and along the banks. 
65. Debris and Ice Is there debris accumulation?

(Yor $N)$ 66. Where? $\underline{Y}$

(1- Upstream; 2- At bridge; 3- Both)

67. Debris Potential 1 (1-Low; 2- Moderate; 3- High)

68. Capture Efficiency 3

(1-Low; 2- Moderate; 3- High)

69. Is there evidence of ice build-up? $\underline{2}$ (Yor $N)$

Ice Blockage Potential $\underline{\mathbf{Y}}$

(1-Low; 2- Moderate; 3- High)

70. Debris and Ice Comments:

2

There are scarred and downed trees US and along the banks, also there are large boulders, $3 \mathrm{ft}$. to $6 \mathrm{ft}$. in diameter, along the banks US and DS. High flow ice is evident by scarred trees US and a 6 ft. log wedged between the $I$ beams and the right abutment about $6 \mathrm{ft}$. above the stream bed.

\begin{tabular}{|l|c|c|c|c|c|c|c|c|}
\hline Abutments & $\begin{array}{c}\text { 71. Attack } \\
\angle \text { (BF) }\end{array}$ & $\begin{array}{c}\text { 72. Slope } \angle \\
\text { (Qmax) }\end{array}$ & $\begin{array}{c}\text { 73. Toe } \\
\text { loc. (BF) }\end{array}$ & $\begin{array}{c}\text { 74. Scour } \\
\text { Condition }\end{array}$ & $\begin{array}{c}75 . \text { Scour } \\
\text { depth }\end{array}$ & $\begin{array}{c}\text { 76. Exposure } \\
\text { depth }\end{array}$ & 77. Material & 78. Length \\
\hline LABUT & & $\mathbf{0}$ & $\mathbf{9 0}$ & $\mathbf{2}$ & $\mathbf{0}$ & - & - & $\mathbf{9 0 . 0}$ \\
\hline RABUT & $\mathbf{1}$ & $\mathbf{5}$ & $\mathbf{9 0}$ & & & $\mathbf{2}$ & $\mathbf{0}$ & $\mathbf{4 5 . 5}$ \\
\hline
\end{tabular}

Pushed: $L B$ or RB

Toe Location (Loc.): 0- even, 1- set back, 2- protrudes

Scour cond.: 0- not evident; 1- evident (comment); 2- footing exposed; 3-undermined footing; 4- piling exposed; 5- settled; 6- failed

Materials: 1- Concrete; 2- Stone masonry or drywall; 3- steel or metal; 4- wood

79. Abutment comments (eg. undermined penetration, unusual scour processes, debris, etc.):

$-$

80. Wingwalls:

Exist? Material? Scour Scour Exposure $\begin{array}{lll}81 . & \\ \text { Angle? Length? }\end{array}$ Condition? depth? depth?

USLWW:

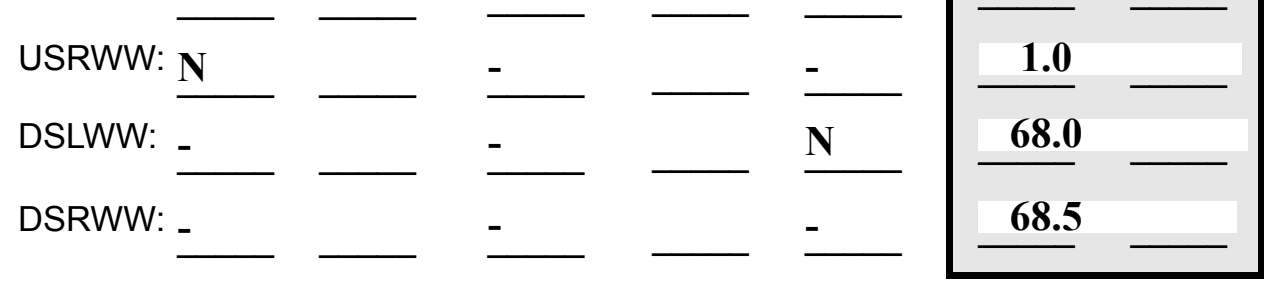

Wingwall materials: 1- Concrete; 2- Stone masonry or drywall; 3- steel or metal; 4- wood

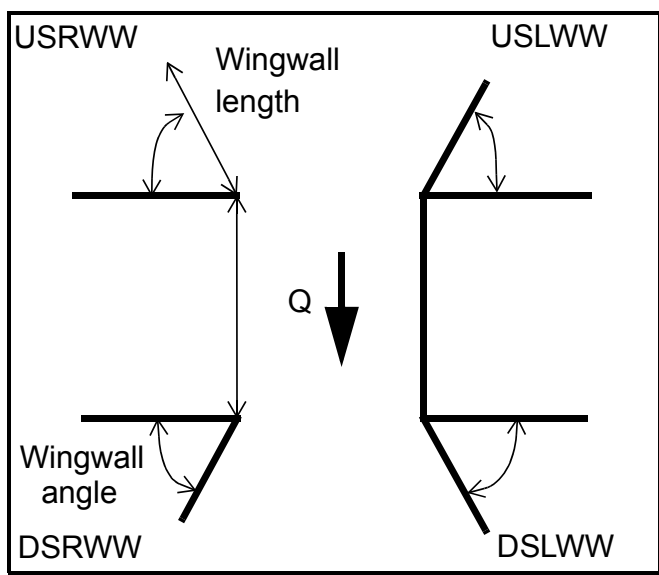

82. Bank / Bridge Protection:

\begin{tabular}{|l|l|l|l|l|l|l|l|l|}
\hline Location & USLWW & USRWW & LABUT & RABUT & LB & RB & DSLWW & DSRWW \\
\hline Type & - & - & N & - & - & - & - & - \\
\hline Condition & N & - & - & - & - & -- & - & - \\
\hline Extent & - & - & - & - & - & - & - & - \\
\hline
\end{tabular}

Bank / Bridge protection types: 0- absent; 1- < 12 inches; 2- < 36 inches; 3- < 48 inches; 4- < 60 inches; 
83. Wingwall and protection comments (eg. undermined penetration, unusual scour processes, etc.):

-
-
-
-
-
-
-
-

\section{Piers:}

84. Are there piers? _ _ (Y or if $N$ type ctrl-n pr)

\begin{tabular}{|l|l|l|l|l|l|l|l|}
\hline \multirow{2}{*}{$\begin{array}{l}85 . \\
\text { Pier no. }\end{array}$} & \multicolumn{3}{|c|}{ width (w) feet } & \multicolumn{3}{c|}{ elevation (e) feet } \\
\cline { 2 - 9 } & w1 & w2 & w3 & e@w1 & e@w2 & e@w3 \\
\hline Pier 1 & - & - & - & - & - & - \\
\hline Pier 2 & - & - & - & - & - & - \\
\hline Pier 3 & - & - & - & - & - & - & - \\
\hline Pier 4 & - & - & - & - & - & w1 \\
\hline
\end{tabular}

\begin{tabular}{|l|l|l|l|l|}
\hline Level 1 Pier Descr. & 1 & \multicolumn{1}{|c|}{2} & 3 & \multicolumn{1}{|c|}{} \\
\hline 86. Location (BF) & & - & - & - \\
\hline 87. Type & & - & - & - \\
\hline 88. Material & & - & - & - \\
\hline 89. Shape & & - & - & - \\
\hline 90. Inclined? & & - & - & - \\
\hline 91. Attack $\angle$ (BF) & & - & - & - \\
\hline 92. Pushed & & - & - & - \\
\hline 93. Length (feet) & - & - & - & - \\
\hline 94. \# of piles & & - & - & - \\
\hline 95. Cross-members & & - & - & - \\
\hline 96. Scour Condition & & - & - & - \\
\hline 97. Scour depth & $\mathbf{N}$ & - & - & - \\
\hline 98. Exposure depth & - & - & - & - \\
\hline
\end{tabular}

LFP, LTB, LB, MCL, MCM, MCR, RB, RTB, RFP

1- Solid pier, 2-column, 3- bent

1-Wood; 2- concrete; 3- metal; 4- stone

1- Round; 2- Square; 3- Pointed

Y-yes; $N$ - no

$L B$ or $R B$

0- none; 1- laterals; 2- diagonals; 3- both

0- not evident; 1- evident (comment);

2- footing exposed; 3- piling exposed;

4- undermined footing; 5- settled; 6- failed 
99. Pier comments (eg. undermined penetration, protection and protection extent, unusual scour processes, etc.):

-
-
-
-
-
-
-
-
-

100.

\section{E. Downstream Channel Assessment}

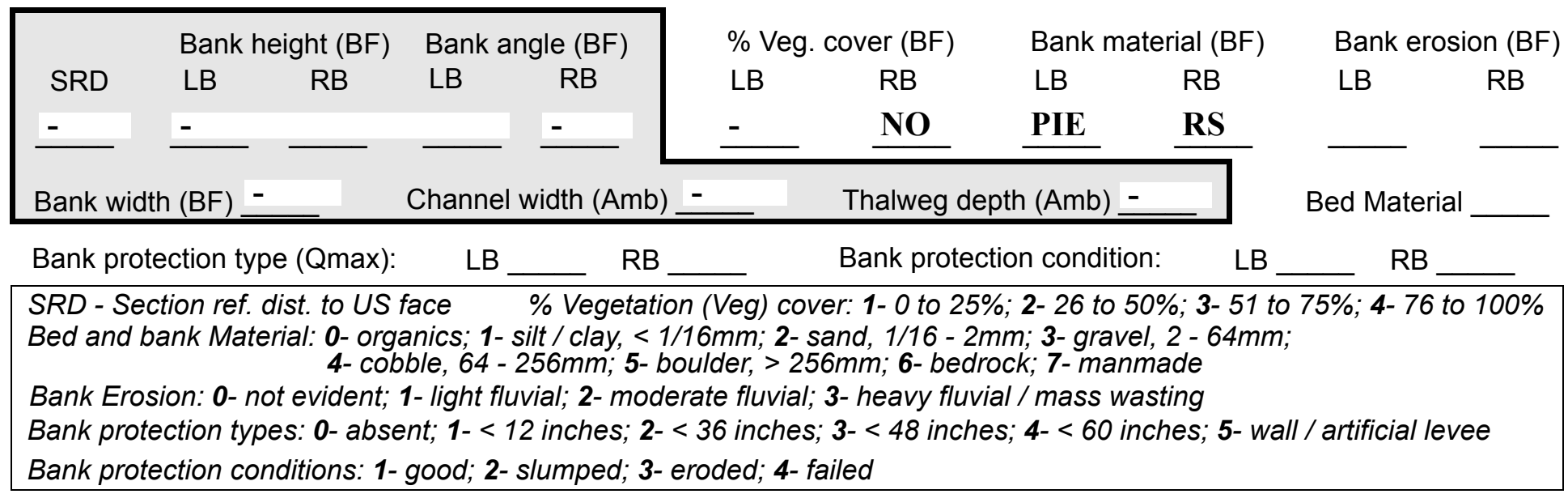

Comments (eg. bank material variation, minor inflows, protection extent, etc.):

2
2
420
4520
2
2
452
1
2
3
3

Bank protection along both banks extends beyond $200 \mathrm{ft}$. DS but the banks are eroding due to high flows and ice conditions. Bank erosion is evident by scalloped banks and exposed tree roots.

101. Is a drop structure present? ___ ( $Y$ or $N$, if $N$ type ctrl-n ds) 102. Distance: ___ feet
103. Drop: - feet
104. Structure material:
(1- steel sheet pile; 2- wood pile; 3-concrete; 4- other)

105. Drop structure comments (eg. downstream scour depth): 
Point bar extent: feet

(US, UB, DS) to $\underline{\mathbf{N}}$ feet (US, UB, DS)

DS) positioned \%LB to DR \%RB

Material: $\mathbf{O P}$

Point or side bar comments (Circle Point or Side; note additional bars, material variation, status, etc.):

\section{STRUCTURE}

Is a cut-bank present? (Y or if $N$ type ctrl-n cb) Where? (LB or $R B)$

Mid-bank distance: $\underline{\mathbf{N}}$

Cut bank extent: feet (US, UB, DS) to feet (US, UB, DS)

Bank damage: (1- eroded and/or creep; 2- slip failure; 3- block failure)

Cut bank comments (eg. additional cut banks, protection condition, etc.):

.

-

$-$

-

Is channel scour present? NO (Y or if N type ctrl-n cs) Mid-scour distance: $\underline{\text { POIN }}$

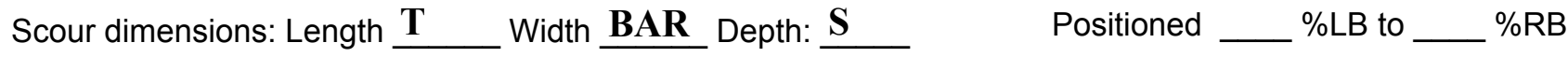

Scour comments (eg. additional scour areas, local scouring process, etc.):

$\mathbf{N}$

$-$

Are there major confluences? ( $Y$ or if $N$ type ctrl-n $m c)$

How many? -

Confluence 1: Distance Enters on ( $L B$ or $R B)$

Type (1- perennial; 2- ephemeral)

Confluence 2: Distance NO Enters on $\underline{\mathbf{C U}}$ (LB or RB)

Type $\underline{\mathbf{T}}$ (1-perennial; 2- ephemeral) Confluence comments (eg. confluence name):

\section{BANKS}

\section{F. Geomorphic Channel Assessment}

107. Stage of reach evolution

1- Constructed

2- Stable

3- Aggraded

4- Degraded

5- Laterally unstable

6- Vertically and laterally unstable 
108. Evolution comments (Channel evolution not considering bridge effects; See HEC-20, Figure 1 for geomorphic descriptors):

$\mathbf{N}$

$-$

$-$

$-$

$-$

$-$

NO CHANNEL SCOUR

$\mathbf{N}$ 


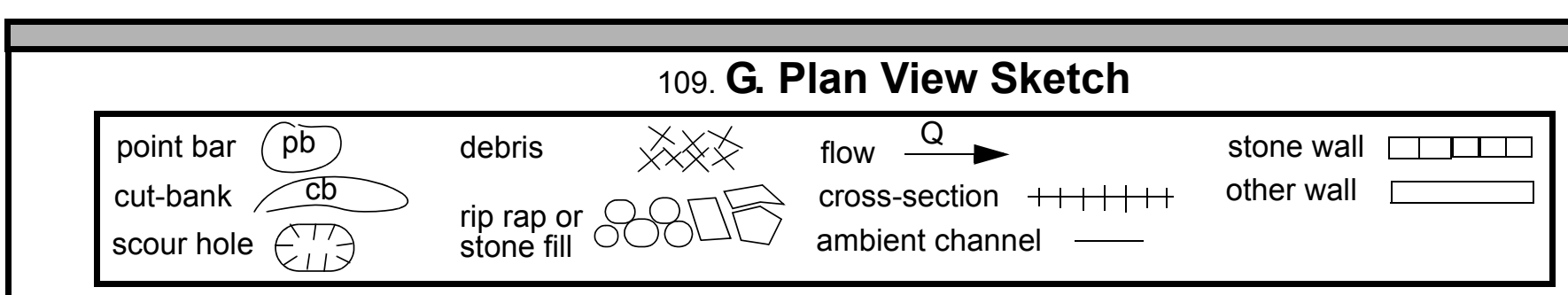


APPENDIX F:

SCOUR COMPUTATIONS 


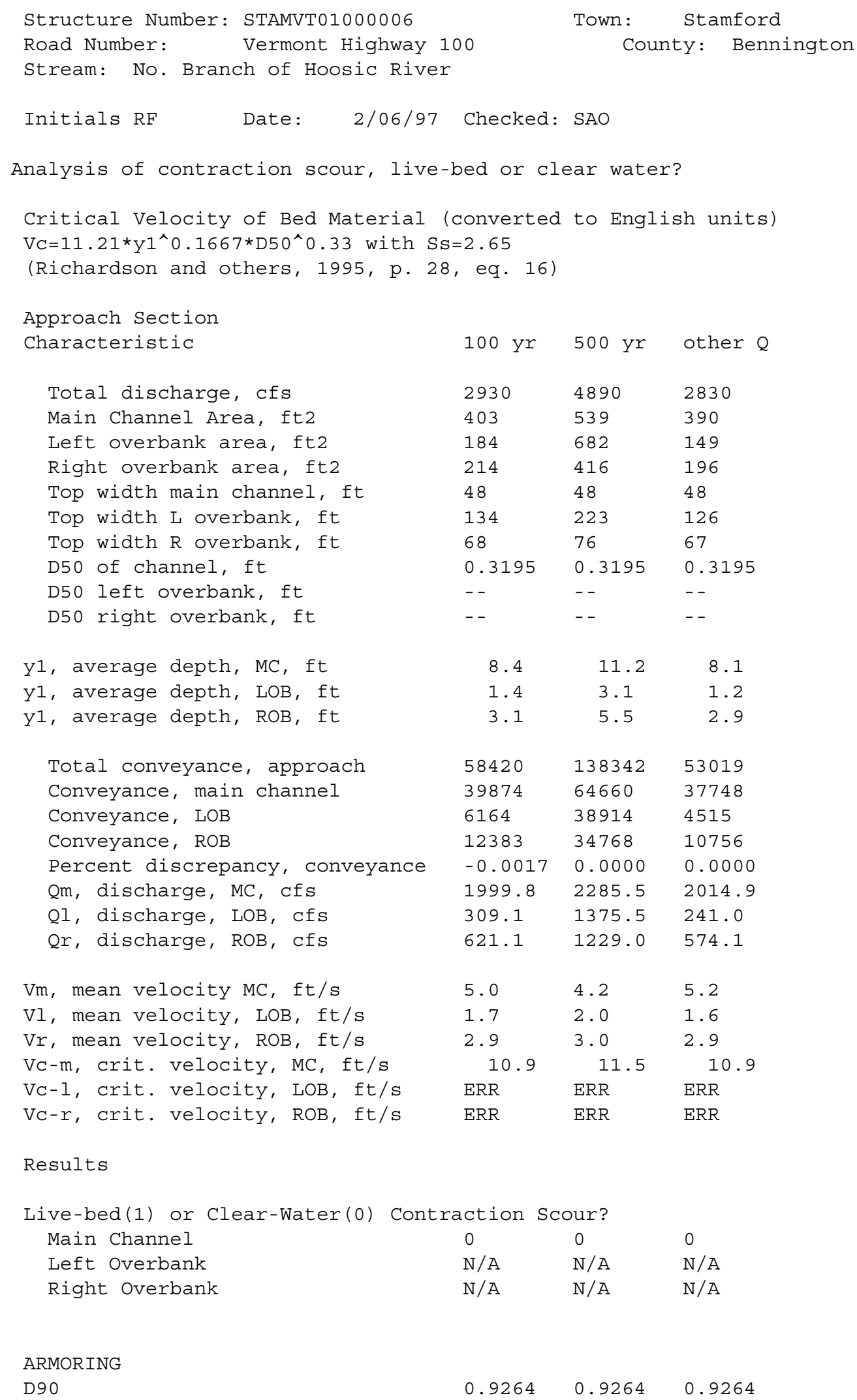


D95

$\begin{array}{lll}1.1968 & 1.1968 & 1.1968 \\ 0.6299 & 0.8136 & 0.5994 \\ 0.1825 & 0.1266 & 0.1933 \\ 8.46 & 16.84 & 7.50\end{array}$

Decimal-percent coarser than Dc

Depth to armoring, ft

8$$
7.50
$$

Clear water Contraction Scour in MAIN CHANNEL

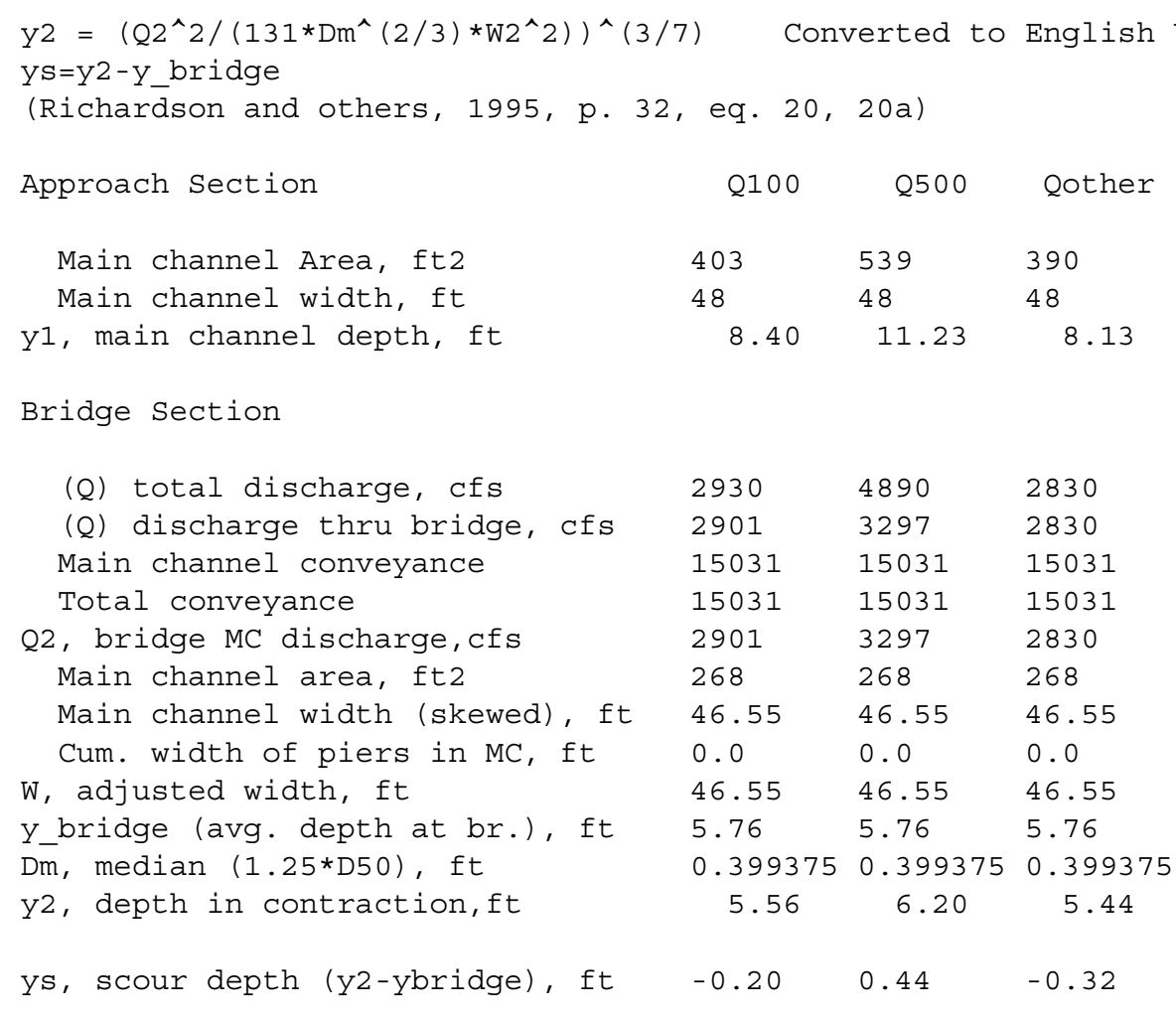

Pressure Flow Scour (contraction scour for orifice flow conditions)

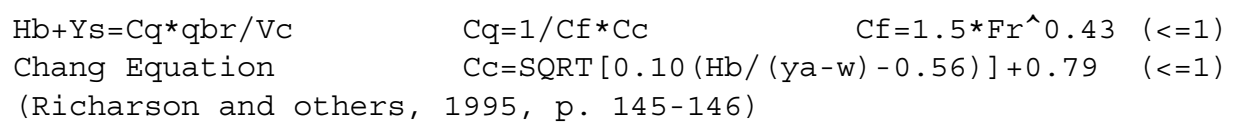

$\begin{array}{llll}\text { Q, total, cfs } & \text { Q100 } & \text { Q500 } & \text { OtherQ } \\ \text { Q, thru bridge, cfs } & 2930 & 4890 & 2830 \\ \text { Total Conveyance, bridge } & 2901 & 3297 & 2830 \\ \text { Main channel (MC) conveyance, bridge } & 15031 & 15031 & 15031 \\ \text { Q, thru bridge MC, cfs } & 2901 & 3297 & 2830 \\ \text { Vc, critical velocity, ft/s } & 10.93 & 11.47 & 10.87 \\ \text { Vc, critical velocity, m/s } & 3.33 & 3.50 & 3.31 \\ \text { Main channel width (skewed), ft } & 46.55 & 46.55 & 46.55 \\ \text { Cum. width of piers in MC, ft } & 0.0 & 0.0 & 0.0 \\ \text { W, adjusted width, ft } & 46.55 & 46.55 & 46.55 \\ \text { qbr, unit discharge, ft2/s } & 62.3 & 70.8 & 60.8 \\ \text { qbr, unit discharge, m2/s } & 5.8 & 6.6 & 5.6 \\ \text { Area of full opening, ft2 } & 268.1 & 268.1 & 268.1\end{array}$




$\begin{array}{llll}\text { Hb, depth of full opening, ft } & 5.76 & 5.76 & 5.76 \\ \text { Hb, depth of full opening, m } & 1.76 & 1.76 & 1.76 \\ \text { Fr, Froude number, bridge MC } & 0.79 & 0.90 & 0.78 \\ \text { Cf, Fr correction factor (<=1.0) } & 1.00 & 1.00 & 1.00 \\ \text { Elevation of Low Steel, ft } & 494.33 & 494.33 & 494.33 \\ \text { Elevation of Bed, ft } & 488.57 & 488.57 & 488.57 \\ \text { Elevation of Approach, ft } & 498.92 & 501.73 & 498.65 \\ \text { Friction loss, approach, ft } & 0.61 & 0.50 & 0.64 \\ \text { Elevation of WS immediately US, ft } & 498.31 & 501.23 & 498.01 \\ \text { ya, depth immediately US, ft } & 9.74 & 12.66 & 9.44 \\ \text { ya, depth immediately US, m } & 2.97 & 3.86 & 2.88 \\ \text { Mean elevation of deck, ft } & 500.215 & 500.215 & 500.215 \\ \text { w, depth of overflow, ft (>=0) } & 0.00 & 1.01 & 0.00 \\ \text { Cc, vert contrac correction (<=1.0) } & 0.85 & 0.79 & 0.86 \\ \text { Ys, depth of scour, ft } & 0.98 & 2.06 & 0.74\end{array}$

Abutment Scour

Froehlich's Abutment Scour

$\mathrm{Ys} / \mathrm{Y} 1=2.27 * \mathrm{~K} 1 * \mathrm{~K} 2 *\left(\mathrm{a}^{\prime} / \mathrm{Y} 1\right) \wedge 0.43 * \mathrm{Fr} 1 \wedge 0.61+1$

(Richardson and others, 1995, p. 48, eq. 28)

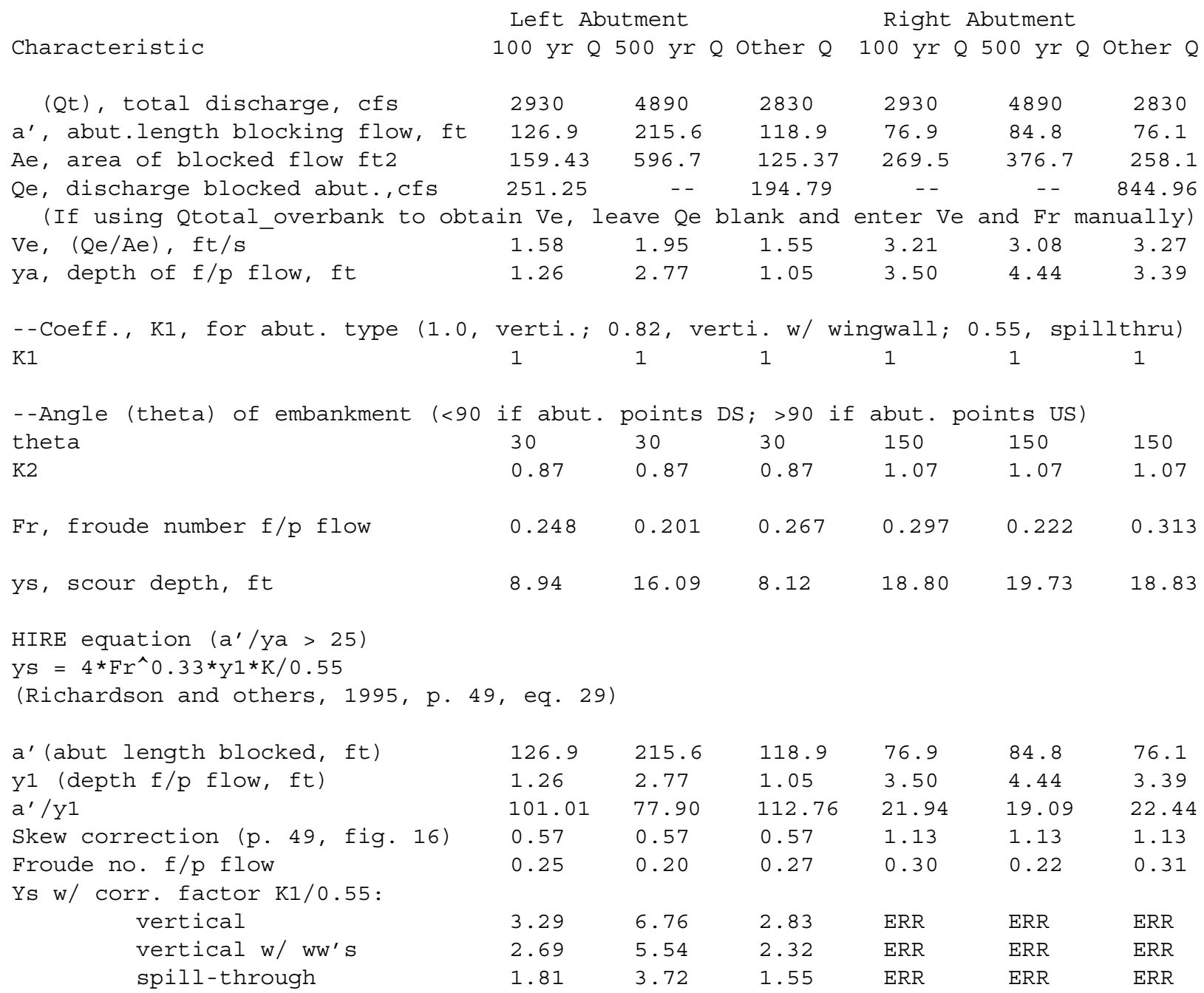




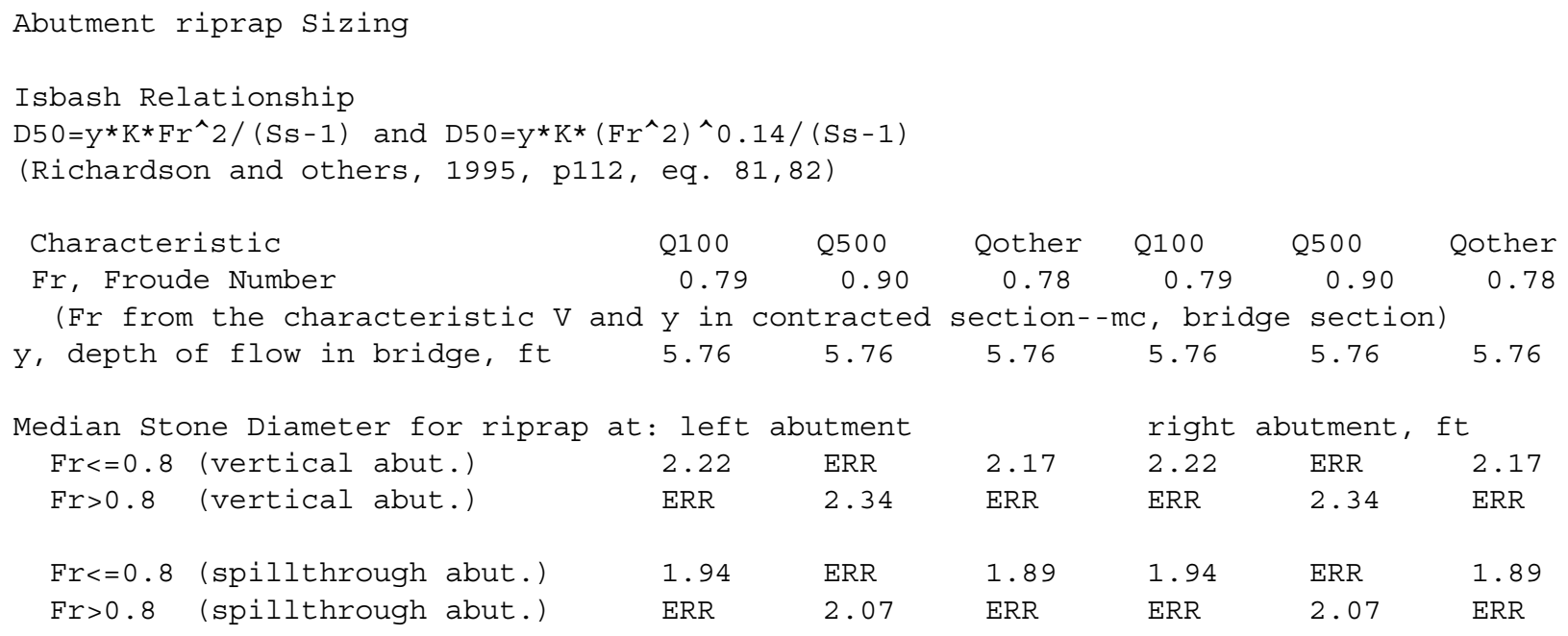

